WeLLINGTON LUIZ FERREIRA DA SiLVA

\title{
Interação do Paracoccidioides brasiliensis com células dendríticas e queratinócitos em biopsias de lesões de pele e mucosa oral
}

Dissertação apresentada a Faculdade de Medicina da Universidade de São Paulo para obtenção do título de Mestre em Ciências

Área de concentração: Dermatologia

Orientadora: Prof ${ }^{a}$ Dr ${ }^{a}$ Mirian Nacagami Sotto

São Paulo 
WeLLINGTON LUIZ FERREIRA DA SiLVA

\section{Interação do Paracoccidioides brasiliensis com células dendríticas e queratinócitos em biopsias de lesões de pele e mucosa oral}

Dissertação apresentada a Faculdade de Medicina da Universidade de São Paulo para obtenção do título de Mestre em Ciências

Área de concentração: Dermatologia

Orientadora: Prof ${ }^{a}$ Dr ${ }^{a}$ Mirian Nacagami Sotto

São Paulo

2016 
Dados Internacionais de Catalogação na Publicação (CIP)

Preparada pela Biblioteca da

Faculdade de Medicina da Universidade de São Paulo

Creprodução autorizada pelo autor

Silva, Wellington Luiz Ferreira da

Interação do Paracoccidioides brasiliensis com células dendríticas e que

queratinócitos em biopsias de lesões de pele e mucosa oral / Wellington Luiz Ferreira da Silva. -- São Paulo, 2016.

Dissertação(mestrado)--Faculdade de Medicina da Universidade de São Paulo. Programa de Dermatologia.

Orientador: Mirian Nacagami Sotto.

Descritores: 1.Paracoccidioidomicose 2.Células dendríticas 3.Queratinócitos 4.Pele 5.Células de Langerhans 6.Mucosa bucal 7.Imuno-histoquímica 8.Microscopia confocal

USP/FM/DBD-080/16 
Aos meus pais pelo apoio integral aos meus estudos e carreira acadêmica... 


\section{AGRADECIMENTOS}

Primeiramente a Deus por ter me concedido a vida e a capacidade de seguir a carreira acadêmica, buscando produzir o conhecimento necessário para, quem sabe um dia, ser aplicado no tratamento de nossos semelhantes;

Aos meus pais por terem me apoiado durante toda a minha vida de estudos, desde os primeiros passos na escola até hoje;

Aos meus irmãos, John Luiz e Maria Luiza e a meus primos que são quase como irmãos: Leugim Ferreira, Karine Ferreira e Wesley Ferreira; adoro esses malucos!!

A todos os meus familiares e que sempre estiveram do meu lado em todos os momentos;

A Kátia Pageu, pela nossa longa convivência e que venham mais longos anos. Eu te amo.

Aos amigos com quem convivi por bons anos na instituição durante 0 curso de graduação, do aprimoramento profissional e o período de pósgraduação e aqueles que convivem e conviveram comigo no dia-a-dia e fins de semana;

À Drâ Mirian Nacagami Sotto, quem me concedeu a primeira oportunidade na pesquisa e por todo o conhecimento e pela brilhante orientação na pós graduação

À Prof ${ }^{a}$ Dra ${ }^{a}$ Maria Irma Seixas Duarte pela ótima receptividade no Programa de Aprimoramento Profissional e por ter me mostrado o emprego das técnicas de imuno-histoquímica no diagnóstico de doenças infecciosas e aplicação em estudo de resposta imune no foco da lesão em diversas doenças; 
À Dra Carla Pagliari, pela orientação e supervisão, sem as quais este trabalho não teria sido desenvolvido;

À Dra Elaine Raniero Fernandes pelo ótimo convívio e auxílio durante a adaptação ao novo ambiente;

Ao Prof. Dr. Thales de Brito, pelos ensinamentos passados em patologia geral no início de minha jornada nesta instituição;

À Ana Maria, colaborando como repasse das técnicas empregadas e auxílio e que me ensinou a técnica aplicada neste trabalho ainda nos tempos de iniciação científica;

À $\operatorname{Dr}^{\mathrm{a}}$ Fernanda Guedes, pelo convívio desde os tempos de iniciação científica;

Aos funcionários da Faculdade de Medicina da Universidade de São Paulo e do Instituto de Medicina Tropical de São Paulo pela convivência durante o período de realização deste e de outros trabalhos. 


\section{LISTA DE FIGURAS}

Figura 1 - Aspecto característico em "roda de leme" do Paracoccidioides brasiliensis em lesão de mucosa oral

Figura 2 - Distribuição geográfica do gênero Paracoccidioides e do L. loboi na América Latina

Figura 3 - Paracoccidioidomicose. Características da resposta tecidual na mucosa oral

Figura 4 - Paracoccidioidomicose - mucosa oral. Coloração de Grocott e técnica de imuno-histoquímica com o anticorpo anti- $P$. brasiliensis

20

Figura 5 - Paracoccidioidomicose. Co-localização do $P$. brasiliensis e dendrócitos dérmicos fator XIIIa

Figura 6 - Paracoccidioidomicose. Técnica imuno-histoquímica de dupla marcação com os anticorpos anti-CD207/Langerina e anti- $P$. brasiliensis 46

Figura 7 - Paracoccidioidomicose: Leveduras do Paracoccidioides brasiliensis no citoplasma de queratinócitos de epitélio de mucosa oral (A) e em pele (B). Notar levedura no interior das células de interesse (Setas). Técnica imunohistoquímica de dupla marcação com os anticorpos AE1/AE3 (marrom) e antiP. brasiliensis (azul)

Figura 8 - Paracoccidioidomicose. Técnica de imunofluorescência de dupla marcação com os anticorpos AE1/AE3 e anti-P. brasiliensis. Análise por microscopia confocal a laser 


\section{LISTA DE TABELAS}

Tabela 1 - Comparação do número de amostras de mucosa oral com leveduras de Paracoccidioides brasiliensis no citoplasma de dendrócitos dérmicos Fator $\mathrm{XIIIa+}$

Tabela 2 - Comparação do número de amostras de mucosa oral e pele com presença de leveduras do Paracoccidioides brasiliensis no citoplasma de queratinócitos 


\title{
LISTA DE ABREVIATURAS, SÍMBOLOS E SIGLAS
}

\author{
AIDS \\ Síndrome da Imunodeficiência Adquirida \\ APC \\ Célula Apresentadora de Antígenos \\ BSA \\ "Bovine Serum Albumin" \\ CAPPEsq \\ Comissão de Ética para Análise de Projetos de \\ Pesquisa
}

Células NK

Células "natural killer"

CD

Células Dendríticas

CDD

Células Dendríticas Dérmicas

DAMPs

Padrões moleculares associados a dano

DC-SIGN

"DC-specific ICAM3-grabbing non-integrin"

DDFXIIla+

Dendrócito Dérmico Fator XIIla positivo

ELISA

Ensaio Imunoenzimático

HIV

Vírus da Imunodeficiência Humana

IFN- $\gamma$

Interferon gama

$\lg$

imunoglobulina

IL-2

Interleucina 2

$\mathrm{IL}-12$

Interleucina 12

LC

Célula de Langerhans

$\mathrm{MHC}$

Complexo Principal de Histocompatibilidade

PAMPs

Padrões moleculares associados a patógenos

PBS

"Phosfate Buffered Saline"

PCM

Paracoccidioidomicose

PCR

Reação de Polimerização em Cadeia

PPR

Receptores de reconhecimento de padrões 
TLR

TNF- $\alpha$
Receptores de tipo"toll"

Fator de Necrose Tumoral alfa 
Esta dissertação está de acordo com as seguintes normas, em vigor no momento desta publicação:

Referências: adaptado de International Committee of Medical Journals Editors (Vancouver).

Universidade de São Paulo. Faculdade de Medicina. Divisão de Biblioteca e Documentação. Guia de apresentação de dissertações, teses e monografias. Elaborado por Anneliese Carneiro da Cunha, Maria Julia de A. L. Freddi, Maria F. Crestana, Marinalva de Souza Aragão, Suely Campos Cardoso, Valéria Vilhena. 3a ed. São Paulo: Divisão de Biblioteca e Documentação; 2011.

Abreviaturas dos títulos dos periódicos de acordo com List of Journals Indexed in Index Medicus. 


\section{SUMÁRIO}

Lista de figuras

Lista de tabelas

Lista de abreviaturas, símbolos e siglas

Resumo

Abstract

1. INTRODUÇÃO 01

2. OBJETIVOS 03

1. Gerais 03

2. Específicos 03

3. REVISÃO DA LITERATURA 05

1. Histórico 05

2. Agente etiológico 07

3. Distribuição geográfica e epidemiologia 09

4. Infecção e patogenia 11

5. Formas Clínicas 13

5.1. Forma aguda/sub-aguda 13

5.2. Forma crônica 14

6. Resposta imune frente ao agente etiológico 15

7. Características histopatológicas da resposta tegumentar na 17

Paracoccidioidomicose

8. Diagnóstico 21

9. Tratamento 23

10. Sistema imune da pele e da mucosa oral 24

10.1. Células dendríticas da pele e mucosa oral 24

10.1.1 Células de Langerhans 25

10.1.2. Células dendríticas dérmicas 26

10.1.3 Células dendríticas nos processos infecciosos de pele e da 28 mucosa oral

10.2. Queratinócitos como células do sistema imune da pele e da 30 mucosa oral 
4. MÉTODOS 31

$\begin{array}{ll}\text { 1. Métodos } & 31\end{array}$

1.1. Casuística 31

1.2. Técnica de dupla marcação para demonstração da 32 interação de DDFXIIla+ com o P. brasiliensis

1.3. Técnica de dupla marcação de células de Langerhas com 35 o P.brasiliensis

1.4. Técnica de dupla marcação de queratinócitos com 36 anticorpo anti-AE1/AE3 e do $P$. brasiensis

1.5. Técnica de dupla marcação por imunofluorescência dos 37 queratinócitos com o anticorpo anti-AE1/AE3 e anticorpo anti- $P$. brasiliensis e observação no microscópio confocal a laser

2. Análise estatística dos resultados 40

5. RESULTADOS 41

1. Análise histopatológica 41

2. Demonstração de colocalização do $P$. brasiliensis no 42 citoplasma de DDFXIIla+

3. Células de Langerhans imunomarcadas pelo anticorpo 44 anti-CD207 (Langerina)

4. Demonstração de colocalização do $P$. brasiliensis no 46 citoplasma de queratinócitos pelas técnicas imunoenzimática e imunofluorescência

5. Análise estatística dos resultados

6. DISCUSSÃO

7. CONCLUSÕES 56

8. SUGESTÕES PARA TRABALHOS FUTUROS 57

9. REFERÊNCIAS 60

10. ANEXOS 69

10.1. Parecer consubstanciado da CAPPEsq 70

10.2. Artigo Ferreira da Silva WL et al, Med Mycol. 2016 Jan 14.71

Pii: myv112 [Epub ahead of print] 


\section{RESUMO}

\section{Silva WLF. Interação do Paracoccidioides brasiliensis com células dendríticas e queratinócitos em biopsias de lesões de pele e mucosa oral [Dissertação]. São Paulo: Faculdade de Medicina, Universidade de São Paulo; 2016.}

A paracoccidioidomicose (PCM) é uma doença sistêmica causada pelos fungos Paracoccidioides brasiliensis e Paracoccidioideslutzii. O comprometimento da pele e mucosa oral são frequentes na PCM. As células dendríticas e queratinócitos do tegumento, devido à sua função como células apresentadoras de antígenos, atuam na resposta imune inata e adaptativa contra agentes patogênicos. Com o objetivo de verificar a interação do $P$. brasiliensis com essas células, estudamos 47 biopsias de mucosa oral e 52 de pele de lesões de doentes com diagnóstico comprovado de PCM. As biopsias foram submetidas à técnica de imuno-histoquímica de dupla-marcação com os anticorpos anti-fator XIlla (marcador de dendrócitos dérmicos), anti-CD207 (marcador de células de Langerhans maduras), anti-pancitoqueratinas (AE1-AE3) e anti-P. brasiliensis. Fez-se também a reação de dupla marcação por técnica de imunofluorescência, com análise por microscopia confocal a laser, para a melhor visualização da interação entre queratinócitos e os fungos. Quarenta e dois por cento das amostras de mucosa oral exibiram formas fúngicas no citoplasma de dendrócitos dérmicos. As células de Langerhans, tanto nas biopsias de mucosa oral como de pele, não mostraram leveduras ou antígenos do fungo no seu citoplasma. Cinquenta e quatro por cento das biopsias de pele e sessenta por cento das amostras de mucosa exibiram leveduras no citoplasma de queratinócitos. Os resultados obtidos permitem concluir que o parasitismo de queratinócitos pode representar possível mecanismo de evasão do fungo aos mecanismos imunes locais. Os dendrócitos dérmicos fator XIIla positivos e queratinócitos podem estar a atuar como células apresentadoras de antígenos para suprir a função, provavelmente prejudicada, das células de Langerhans nas lesões de pele e mucosa oral da PCM humana.

Descritores: Paracoccidioidomicose; células dendríticas; queratinócitos; pele; células de Langerhans; mucosa bucal; imuno-histoquímica; microscopia confocal. 
ABSTRACT

Silva WLF. Paracoccidioides brasiliensis interacts with dermal dendritic cells and keratinocytes in human skin and oral mucosa lesions [Dissertation]. São Paulo: "Faculdade de Medicina, Universidade de São Paulo"; 2016.

Paracoccidioidomycosis (PCM) is a systemic disease caused by the fungus Paracoccidioides brasiliensis, which compromises various organs, mainly the lungs. The skin and oral mucosa are often affected. Dendritic cells and keratinocytes of the integument play a role in innate and adaptive immune response against pathogens, due to their function as antigen presenting cells. Aiming to verify the interaction of $P$. brasiliensis with these cell populations, we studied 52 biopsies of skin and 47 oral mucosa samples taken from patients with proven diagnosis of PCM. The biopsies were subjected to double immune staining technique with anti-factor XIIla (marker of dermal dendrocytes), antiCD207 (marker of mature Langerhans cells), anti-pan cytokeratins (AE1-AE3) and anti $P$. brasiliensis antibodies. Analyses with confocal laser microscopy were also performed to better visualization of the interaction between keratinocytes and the fungi. Factor XIIla + dermal dendrocytes of $42 \%$ samples of oral mucosa displayed yeast forms in their cytoplasm. We did not observe yeast cells in the cytoplasm of Langerhans cells in both skin and oral mucosa samples. Fifty -four percent of skin and $60 \%$ of mucosal samples displayed yeast cells in the cytoplasm of keratinocytes. The parasitism of keratinocytes may represent a possible mechanism of evasion of the fungus to local immune mechanisms, or even as a result of keratinocytes ability to antigen presentation in PCM. Factor XIIla dendrocytes and keratinocytes may be acting as antigenpresenting cells to fulfill the function of Langerhans cells, probably impaired, in skin and mucosa of human PCM.

Descriptors: paracoccidioidomycosis; dendritic cells; keratinocytes; skin; Langerhans cells; mouth mucosa; immunohistochemistry; confocal microscopy. 


\section{CAPÍTULO 1 - INTRODUÇÃO}

A Paracoccidioidomicose (PCM) é uma doença sistêmica causada por um fungo dimórfico, o Paracoccidioides sp. O pulmão é o órgão mais afetado, sendo a pele, mucosas oral e do trato respiratório alto frequentemente acometidas.

Nos sítios de lesão o fungo adquire a forma em levedura e interage com o macrófago que é a principal célula de defesa (Bocca et al., 1999).

A resposta tecidual na $\mathrm{PCM}$ é de tipo granulomatosa. A organização dessa resposta tecidual, nos sítios de lesão, relaciona-se com a capacidade de resposta imunológica do hospedeiro (Franco et al., 2006).

As células dendríticas, assim como os queratinócitos da pele e mucosas participam da resposta imune inata e adaptativa contra patógenos e agentes infecciosos (Nestle et al., 2009).

As células de Langerhans são consideradas as principais células apresentadoras de antígenos. Entretanto, outras células dendríticas presentes na pele e mucosas também são envolvidas na imunidade contra esses agentes agressores (Collin et al., 2013). 
Os dendrócitos dérmicos, caracterizados pela expressão citoplasmática do fator de coagulação XIIla, estão presentes na pele normal onde distribuemse ao redor dos vasos superficiais da derme e adventícia dos anexos cutâneos (Quatrezzos et al., 2008). Os dendrócitos dérmicos fator XIlla positivos (DDFXIIla+) apresentam função de apresentação antigênica e influenciam a migração de linfócitos na pele através de sua capacidade de secreção de fator de necrose tumoral alfa (Nestle et al, 1998; Paquet et al., 2000).

São poucos os trabalhos na literatura que enfocam a interação do $P$. brasiliensis com células dendríticas (Pagliari e Sotto, 2002) e queratinócitos nos sítios de lesão da PCM humana (de Brito et al., 1973) e em condições experimentais (da Silva et al., 2011). Desse modo, pareceu-nos interessante verificar a interação do fungo com esses elementos celulares nas lesões de pele e mucosa oral na PCM, visando contribuir para o melhor entendimento dos mecanismos imunopatológicos dessa micose sistêmica endêmica em nosso país. 


\section{CAPÍTULO 2 - OBJETIVOS}

\section{GERAIS}

Verificar a interação do Paracoccidioides brasiliensis com células dendríticas e queratinócitos das lesões tegumentares da paracoccidioidomicose.

\section{ESPECIFICOS}

Verificar se ocorre a colocalização do Paracoccidioides brasiliensis com os dendrócitos dérmicos em biopsias de lesões de mucosa oral;

com as células de Langerhans de lesões de pele e com mucosa oral;

com queratinócitos epidérmicos e do epitélio de revestimento das lesões de pele e mucosa oral. 
Comparar a frequência de colocalização do fungo com esses elementos celulares, nas biopsias de pele e mucosa oral, classificadas de acordo com as características da resposta tecidual (granulomas bem formados, frouxos e com os dois tipos de granulomas no mesmo preparado). 


\section{CAPÍTULO 3 - REVISÃO DA LITERATURA}

A Paracoccidioidomicose (PCM) é uma doença sistêmica causada por um fungo dimórfico, o Paracoccidioides sp. O pulmão é o órgão mais afetado, sendo as lesões de pele, mucosas oral e do trato respiratório alto frequentemente acometidas.

A PCM é endêmica na América Latina, com regiões de maior ou menor endemicidade (Minami, 2003; Franco,et al. 2006; Shikanai-Yasuda, et al, 2006). Acomete, sobretudo, indivíduos do sexo masculino residentes em áreas rurais. A maioria dos pacientes manifesta a forma crônica, típica de indivíduos adultos.

\section{HISTÓRICO}

A PCM foi descrita por Adolfo Lutz em 1908 ao observar lesões em mucosa oral de dois pacientes internados na Santa Casa de São Paulo. Descreveu com detalhes os aspectos clínicos das lesões e fez o isolamento do fungo em cultura, entretanto, sem nomeá-lo. De acordo com Sidrim e Rocha (2004), Lutz diferenciou a PCM da coccidioidomicose, que havia sido descrita alguns anos antes.

Splendore, entre os anos de 1909-1912, aos estudar quatro casos de pacientes que apresentavam lesões em mucosa oral semelhantes aos casos 
descritos por Lutz em 1908, observou que os fungos em cultura eram iguais aos descritos por Lutz. Nomeu o fungo como Zimonema brasiliensis (Lacaz, 2002).

De acordo com Lacaz (2002), outros pesquisadores também descreveram essa doença. No entanto, os trabalhos de Splendore impulsionaram o estudo clínico e micológico da doença.

A proposição do nome Paracoccidioides brasiliensis foi feita apenas em 1930 pelo médico e micologista Floriano Paulo de Almeida após uma série de estudos iniciados em 1927 que demonstraram que o agente era distinto do agente dos granulomas coccidioídicos, criando, então, o gênero Paracoccidioides e validou a espécie brasiliensis (Lacaz, 2002).

Segundo Sidrim e Rocha (2004), até 1971, a PCM era denominada de blastomicose brasileira e micose de Lutz. Com a observação de casos da micose em outros países sul-americanos entre 1940 e 1970, o termo predominante para denominá-la era Blastomicose sul-americana. O nome paracoccidioidomicose foi empregado a partir do "Pan American Symposium on Paracoccidioidomycosis" (1971), tornando esse nome da doença conhecido e amplamente aceito no meio médico. 


\section{AGENTE ETIOLÓGICO}

Até o ano de 2006 considerou-se que o agente causador da paracoccidioidomicose era o Paracoccidioides brasiliensis. Através de estudo por "Multi Locus Sequence Typing" (MLST), foram descritas quatro formas crípticas, sendo três do complexo $P$. brasiliensis (S1, PS2 e PS3) e o Paracoccidioides lutzii (Theodoro et al., 2012; Bocca et al., 2013).

O Paracoccidioides é um fungo termo-dimórfico. Apresenta-se na forma miceliana em temperatura variante entre 19 e $25^{\circ} \mathrm{C}$. Assume a forma de levedura em temperaturas próximas a $37^{\circ} \mathrm{C}$, que são observadas nas lesões teciduais dos pacientes.

As leveduras são as formas parasitárias do fungo e têm formato arredondado com diâmetro que pode variar de 5 a $40 \mu \mathrm{m}$. Apresentam uma parede espessa de dupla camada (Sidrim e Rocha, 2004). Lacaz (2002) chamam a atenção para a exoesporulação múltipla (mais de quatro gêmulas) que é característica desse fungo quando observado ao microscópio, a chamada "roda-de-leme" ou "timão" (figura 1)

Esse formato típico do Paracoccidioides deve-se ao modo de reprodução das leveduras. Os brotamentos são blastoconídios de 2 a $10 \mu \mathrm{m}$ que se dispõem ao redor da levedura-mãe, à qual estão ligados por pontes celulares estreitas e curtas (Sidrim e Rocha, 2004).

O fungo possui uma parede celular composta por duas camadas, que Ihe dão um aspecto birrefringente no exame a fresco. Na levedura, essa parede 
é composta principalmente por a-glucana e quitina. Em estudos de microscopia eletrônica, observou-se que a parede externa é mais fina e composta principalmente por fibrilas de a-glucana e a parede interna é mais espessa e composta principalmente por quitina (Carbonell, 1969).

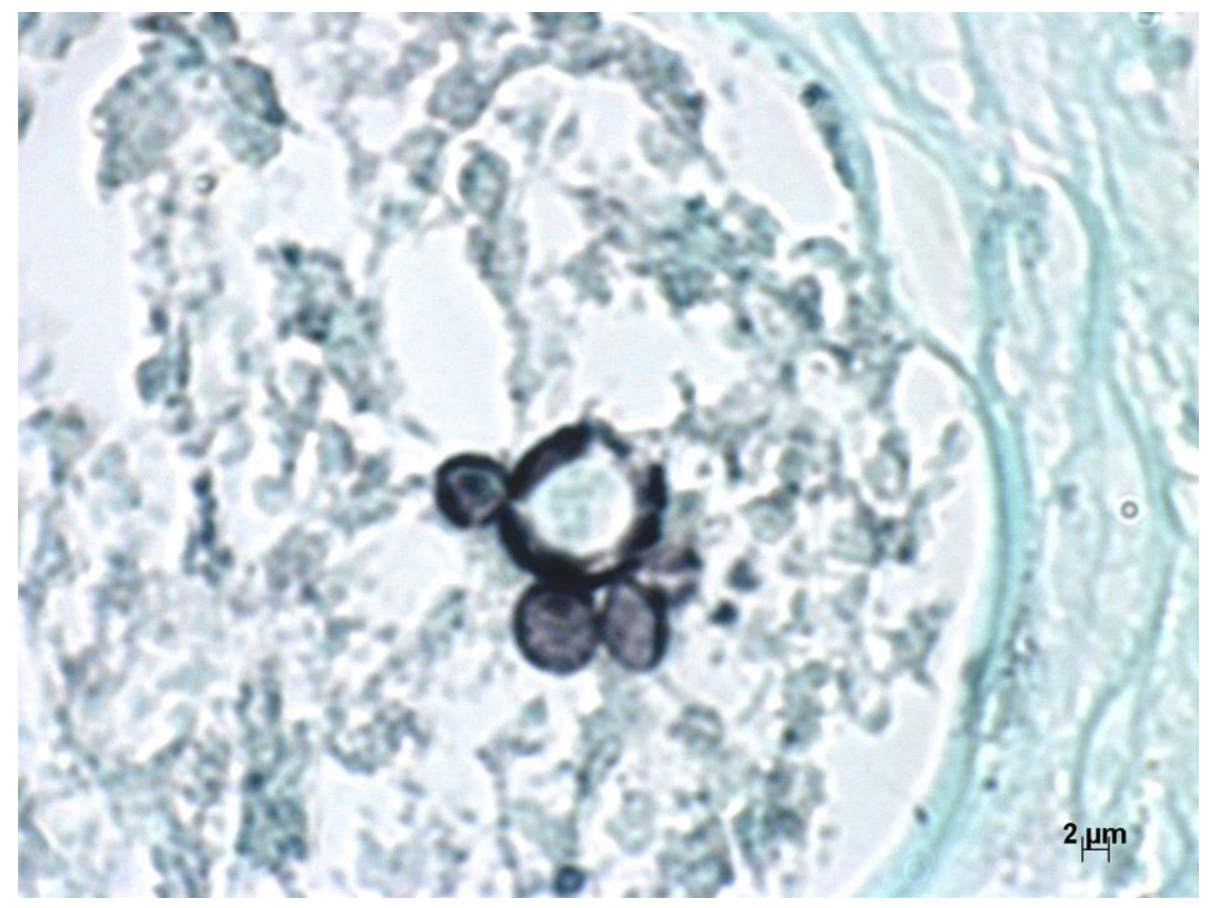

Figura 1: Aspecto característico em "roda de leme" do Paracoccidioides brasiliensis em lesão de mucosa oral. Coloração de Grocott, aumento original de $1000 x$

Franco et al. (2006) afirmam que diversos dados sobre a ecologia do fungo ainda estão no terreno das hipóteses, porém, assim como Sidrim e Rocha (2004), acreditam que o hábitat natural do fungo seja o solo, uma vez que há evidências de que o fungo seja um saprófita quando em vida livre, lembrando ainda que, apesar de diversas tentativas, o $P$. brasiliensis só foi 
isolado, com certeza, em apenas três ocasiões, a partir de amostras de solo de regiões endêmicas do Brasil, Argentina e Venezuela.

Almeida et al. (2003) referem que a patogenicidade do fungo pode estar associada a moléculas de sua membrana, como a a-1-3-glucan e glicoproteína 43 (gp43) caracterizada por Mendes Giannini et al. (1989).

Na natureza, o $P$. brasiliensis apresenta-se como estruturas filamentosas contendo propágulos infectantes chamados conídios, que, quando inalados, dão origem às leveduras do fungo que constituirão sua forma parasitária nos tecidos do hospedeiro. Os humanos eram tidos como os únicos hospedeiros naturalmente infectados por este fungo, porém, relatos mostraram alguns animais infectados pelo fungo (Shikanai-Yasuda et al., 2006).

\section{DISTRIBUIÇÃO GEOGRÁFICA E EPIDEMIOLOGIA}

A doença se distribui geograficamente por toda a América Latina de maneira heterogênea, desde o México até a Argentina, porém, alguns países na América do Sul e América Central não possuem registros de casos autóctones, sendo a maior parte dos casos registrada no Brasil, Colômbia e Venezuela (Almeida et al, 2003; Sidrim e Rocha, 2004; Franco et al, 2006; Shikanai-Yasuda et al, 2006; Ferreira, 2009; Marques, 2012).

No Brasil, A PCM é pouco frequente nas Regiões Nordeste e Norte, sendo frequente nas outras regiões do país, principalmente nas Regiões 
Sudeste e Sul (Muniz et al, 2002; Almeida et al, 2003). A figura 2 demonstra a distribuição geográfica dos casos relacionados aos agentes do complexo $P$. brasiliensis e $P$. lutzii.

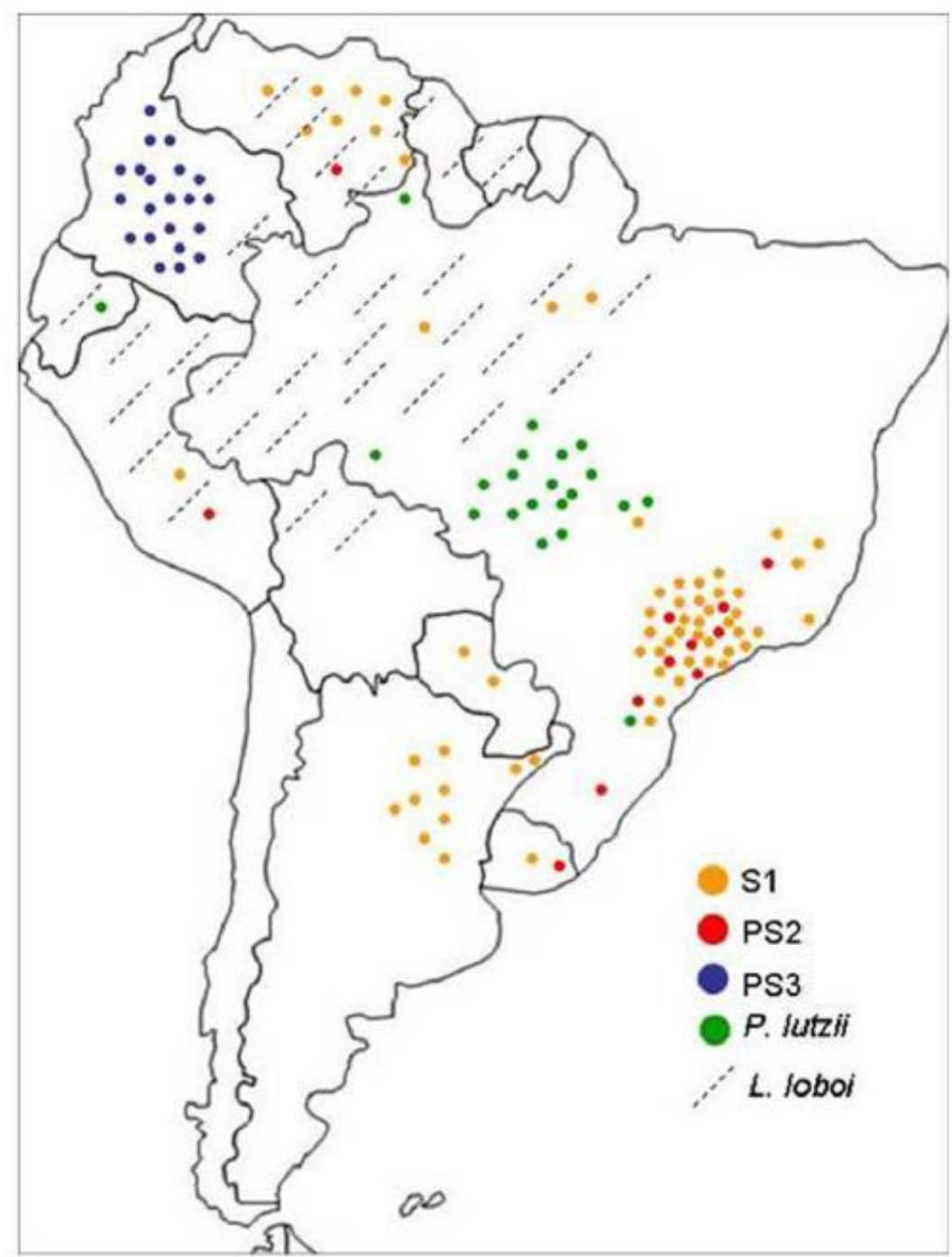

Figura 2. Distribuição geográfica do gênero Paracoccidioides e do L. loboi na América Latina (fonte Theodoro et al., 2012)

A PCM acomete principalmente homens adultos na faixa etária dos 30 aos 50 anos moradores e trabalhadores de zonas rurais, com pico da infecção entre os 10 e 20 anos de idade, podendo permanecer latente por vários anos. 
É descrito ainda que essa prevalência maior da doença em indivíduos do sexo masculino não é observada nas formas juvenis, onde, até os 20 anos de idade, há equivalência entre os infectados de ambos os sexos (Lupi et al.,2005; Shikanai-Yasuda et al. 2006; Ferreira, 2009; Marques, 2012).

Entre os fatores relacionados com o desenvolvimento da PCM destacam-se o alto consumo de álcool, tabagismo e má nutrição. Esses fatores propiciam o desequilíbrio da relação parasita-hospedeiro, o que favorece a multiplicação e disseminação das leveduras e desenvolvimento da PCM (Ferreira, 2009; Marques, 2012).

É descrito que o estrógeno parece possuir um papel protetor à infecção nas mulheres, o que explicaria uma maior incidência da doença em indivíduos do sexo masculino. O fungo possui receptores para estrógeno. Esse hormônio inibe in vitro a transformação dos conídios fúngicos para leveduras (Restrepo et al. 1984; Shankar et al., 2011).

\section{INFECÇÃO E PATOGENIA}

O homem infecta-se a partir da inalação de conídios (Lupi et al., 2005; Franco et al., 2006; Shikanai-Yasuda et al., 2006). O fungo produz grande quantidade de conídios e estes atingem facilmente os alvéolos pulmonares, o que se comprova nos modelos de animais de experimentação (Franco et al., 2006). A PCM, diferente do que se observa em outras micoses como a histoplasmose disseminada e a criptococose, não tem uma relação direta com 
a imunodepressão, apesar de haver casos descritos em pacientes com AIDS e portadores de neoplasias malignas e, raramente, transplantados (ShikanaiYasuda et al., 2006).

O primeiro contato com o P. brasiliensis ocorre, geralmente, nas duas primeiras décadas de vida do hospedeiro, porém, com raro desenvolvimento da PCM doença nesse período. A infecção pode permanecer durante anos na forma latente, sendo incomum a apresentação clínica da doença nesse período (Shikanai-Yasuda et al.,2006, Ferreira, 2009).

A PCM também pode ser adquirida em contato direto através de pequenas lesões teciduais, o que explicaria a infecção e o raro desenvolvimento da doença sem o envolvimento pulmonar (Franco et al., 2006).

A inalação dos conídios do $P$. brasiliensis com sua posterior transformação em leveduras e disseminação linfática são considerados os mecanismos de infecção e disseminação da doença, não sendo descrita a transmissão de uma pessoa com PCM para outro indivíduo sadio (Almeida et al. 2003).

O estabelecimento dos fungos depende da transformação dos conídios em leveduras por mecanismos ainda não bem descritos.

O foco inicial da doença ocorre nos pulmões. Após a transformação dos conídios em leveduras nos sítios pulmonares, os fungos podem ser destruídos pelo sistema imune do hospedeiro ou serem drenados para linfonodos regionais, causando um complexo primário da infecção, com posterior 
disseminação hematogênica do agente para focos secundários em diversos órgãos, formando os focos secundários. Os focos primários podem ainda regredir com a destruição dos fungos, ou com permanência de fungos viáveis nas cicatrizes (Franco et al., 2006).

\section{FORMAS CLÍNICAS}

De acordo com Shikanai-Yasuda et al. (2006), a classificação mais utilizada para diferenciar as formas clínicas da PCM foi apresentada em 1986 no "International Colloquium on Paracoccidioidomycosis" realizado em Medellín, Colômbia, sendo bem definidas duas formas bem distintas entre si, levando-se em conta a gravidade, a população atingida e as manifestações clínicas; a Forma Aguda/Sub-aguda, também conhecida como Juvenil e a Forma Crônica, ou do adulto.

\subsection{Forma Aguda/Sub-aguda}

Essa forma manifesta-se em crianças e jovens de ambos os sexos, com ligeira maioria de pacientes do sexo masculino e ocorre entre 5 e $10 \%$ dos casos da doença. Caracteriza-se por uma rápida evolução, destacando-se linfadenomegalia, manifestações digestivas, hepatoesplenomegalia, envolvimento ósteo-articular e lesões cutâneas, sendo raro o envolvimento 
pulmonar e da mucosa oral (Almeida et al., 2003; Shikanai-Yasuda et al., 2006; Ramos-e-Silva e Saraiva, 2008; Ferreira, 2009; Marques, 2012).

Franco et al (2006) ressaltam que a disseminação linfo-hematogênica contribui para o rápido desenvolvimento da doença e que, nesses casos, a resposta imune humoral está preservada devido aos altos títulos de anticorpos encontrados nesses pacientes, porém, há uma supressão da resposta imune celular, necessária para a proteção do hospedeiro.

Ramos-e-Silva e Saraiva (2008) afirmam que o acometimento de mucosas nessa manifestação clínica é raro, embora seja registrada a frequente manifestação cutânea.

\subsection{Forma Crônica}

A Forma crônica de manifestação da PCM ocorre em cerca de $90 \%$ dos pacientes. Atinge, principalmente, indivíduos do sexo masculino (proporção de cerca de 15 homens doentes para 1 mulher doente) com idade entre 30 e 60 anos.

A doença tem progressão mais lenta e o envolvimento pulmonar é muito frequente, podendo haver disseminação a partir desse foco inicial. A PCM pode ser considerada unifocal, quando há apenas o acometimento de um órgão ou sistema, podendo ser restrita apenas ao pulmão, ou multifocal, mais comum, 
com frequente envolvimento de pele e mucosas (Franco et al., 2006; ShikanaiYasuda et al., 2006; Ramos-e-Silva e Saraiva, 2008; Ferreira, 2009).

Franco et al. (2006) ainda lembram que a resposta imune celular está preservada e a resposta imune humoral está presente, porém os níveis de anticorpos são mais baixos quando comparados com os de pacientes portadores da forma aguda/sub-aguda da doença e que pode haver comprometimento de pele e mucosa oral (forma tegumentar) sem 0 envolvimento pulmonar, embora muito raro.

\section{RESPOSTA IMUNE FRENTE AO AGENTE ETIOLÓGICO}

Na PCM o controle da infecção depende, sobretudo, da ativação da resposta imune celular através de citocinas do padrão Th1, como o interferon gama (IFN-ү) e as interleucinas 2 e 12 (IL-2 e IL-12), para ativação de macrófagos e linfócitos, com formação de granulomas epitelioides e eliminação do fungo (Ferreira, 2009; Parise-Fortes et al., 2011).

A participação do sistema fagocitário é uma importante linha de defesa contra o fungo, pois trabalhos experimentais utilizando camundongos com essa linhagem celular bloqueada desenvolveram lesões extensas com grande número de parasitas (Franco et al., 2006). 
Pacientes com PCM apresentam diminuição da resposta imune celular, com queda dos níveis sanguíneos de linfócitos T CD4+ e T CD8+ possivelmente associada ao aumento dos níveis de IL-4 (Almeida et al., 2003).

A forma juvenil (aguda) da PCM está associada com exacerbação da resposta Th2, sendo observados altos títulos de anticorpos das classes lgG, $\lg$ E e IgA, baixa quantidade de IFN-y e altos níveis de citocinas de perfil Th2. Nesses doentes 0 teste com a paracoccidioidina demonstra 0 comprometimento da resposta imune celular. Histologicamente nota-se a presença de granulomas mal-formados e um grande número de fungos nas lesões.

$\mathrm{Na}$ forma crônica (ou do adulto) os títulos de anticorpos são mais baixos quando comparados com a forma juvenil. A resposta imune celular é melhor preservada, o que é comprovado pelo teste positivo da paracoccidioidina. A resposta tecidual é caracterizada por número menor de fungos e a presença de granulomas epitelioides bem organizados. Os fungos mostram-se no citoplasma de células gigantes multinucleadas (Franco et al., 2006).

Pagliari e Sotto (2003) ao estudar lesões de pele de PCM observaram maior expressão de IFN-y nos casos onde a resposta tecidual apresentava granulomas bem formados. Por outro lado, havia maior expressão de IL-5 e IL10 nas lesões com granulomas frouxos.

As células "natural killer" (NK) inibem o crescimento e a sobrevivência do $P$. brasiliensis "in vitro". Os pacientes com PCM apresentam redução dessa 
população celular. O sistema complemento propicia a fagocitose através da opsonização do fungo (Franco et al., 2006).

Recentemente foi demonstrada a participação da resposta imune de perfil Th17 na PCM humana (Pagliari et al., 2011; de Castro et al., 2013). Esse perfil imunológico estaria relacionado com as alterações inflamatórias destrutivas e consequente fibrose observadas na forma de PCM do adulto (de Castro et al., 2013).

O envolvimento das células dendríticas e de queratinócitos na patogenia da PCM será revisado à frente no item Sistema imune da pele e mucosa oral.

\section{CARACTERÍSTICAS HISTOPATOLÓGICAS DA RESPOSTA TEGUMENTAR NA PARACOCCIDIOIDOMICOSE}

As alterações histológicas encontradas em mucosa oral e na pele são semelhantes (Franco et al., 2006). São frequentemente observadas a hiperplasia epitelial e mesmo a hiperplasia pseudocarcinomatosa. O processo inflamatório é frequentemente de tipo granulomatoso. A presença de microabscessos intraepiteliais, com quantidade variável de fungos é característica frequente das lesões tegumentares (Franco et al., 2006).

O padrão dos granulomas é tuberculoide, com células epitelioides e células gigantes multinucleadas, podendo conter fungos em seu interior. A presença de elementos como focos supurativos nos centros dos granulomas, 
linfócitos, macrófagos e, eventualmente, eosinófilos, auxiliam no diagnóstico diferencial com outros processos granulomatosos (Franco et al. 2006). De Brito et al. (1973) e Sandoval et al. (1995) relataram a presença de fungos no epitélio de revestimento de pele e mucosa oral.

O tipos de granulomas encontrados nas lesões pode variar de acordo com o quadro clínico do paciente. Pode haver a formação de granulomas compactos e bem definidos ou a formação de granulomas frouxos e mal definidos com grande número de leveduras na lesão (figura 3). As características e organização da resposta granulomatosa são associadas ao grau de resposta imune do hospedeiro (Almeida et al., 2003; Franco et al., 2006).

O diagnóstico histopatológico pode ser facilitado com o emprego de técnicas de colorações específicas para visualização dos fungos, como o Grocott, PAS, Gridley ou o emprego de técnica de imuno-histiquímica com anticorpos específicos contra determinados elementos do fungo (figura 4). 

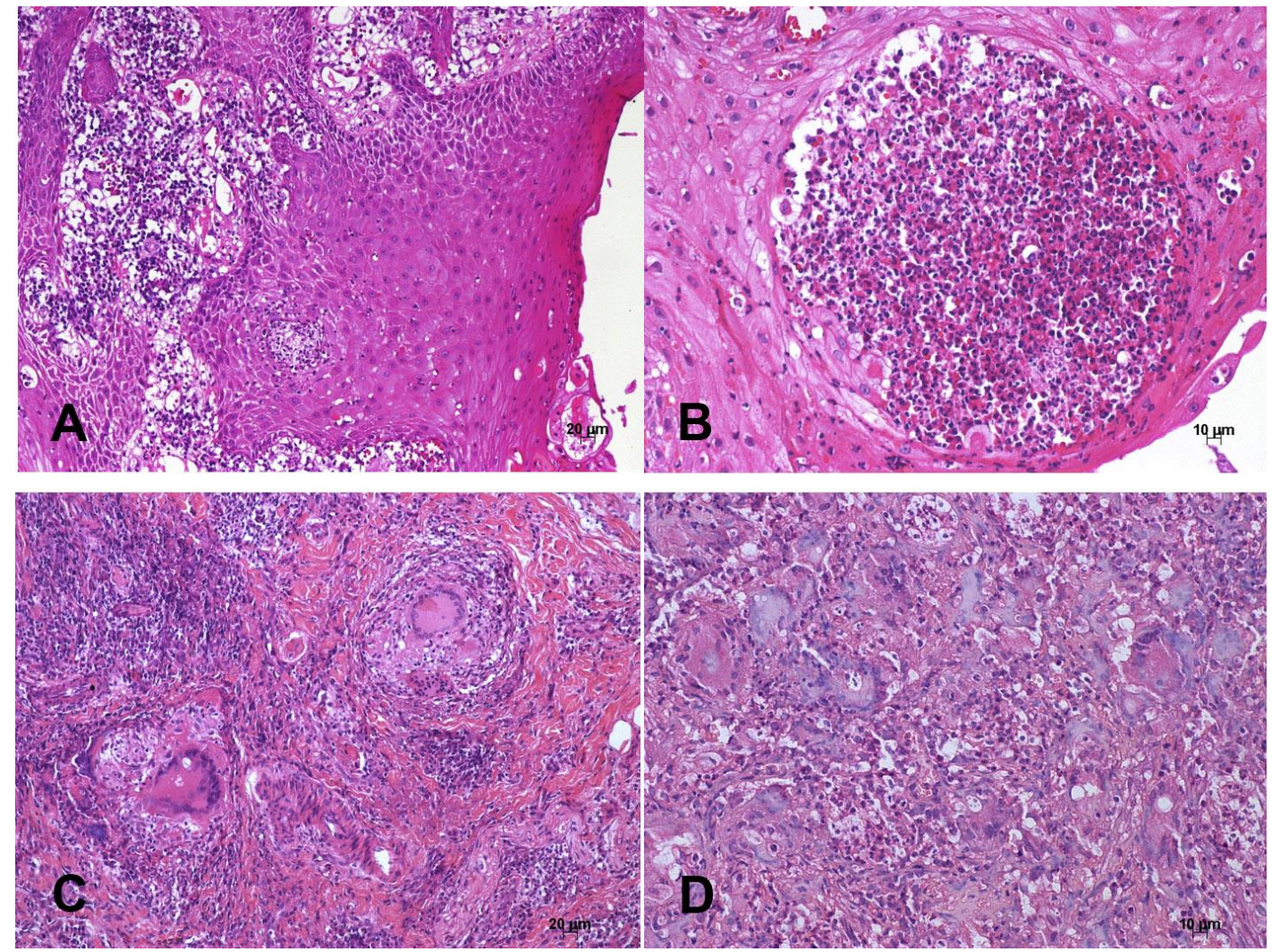

Figura 3. Paracoccidioidomicose - mucosa oral. A - hiperplasia pseudocarcinomatosa do epitélio. B - Microabscesso intraepitelial. C Granuloma epitelióide bem organizado. Notar fungos no citoplasma de gigantócito. D - Granuloma pouco organizado (frouxo) com numerosos fungos. Coloração de hematoxilina-eosina. 


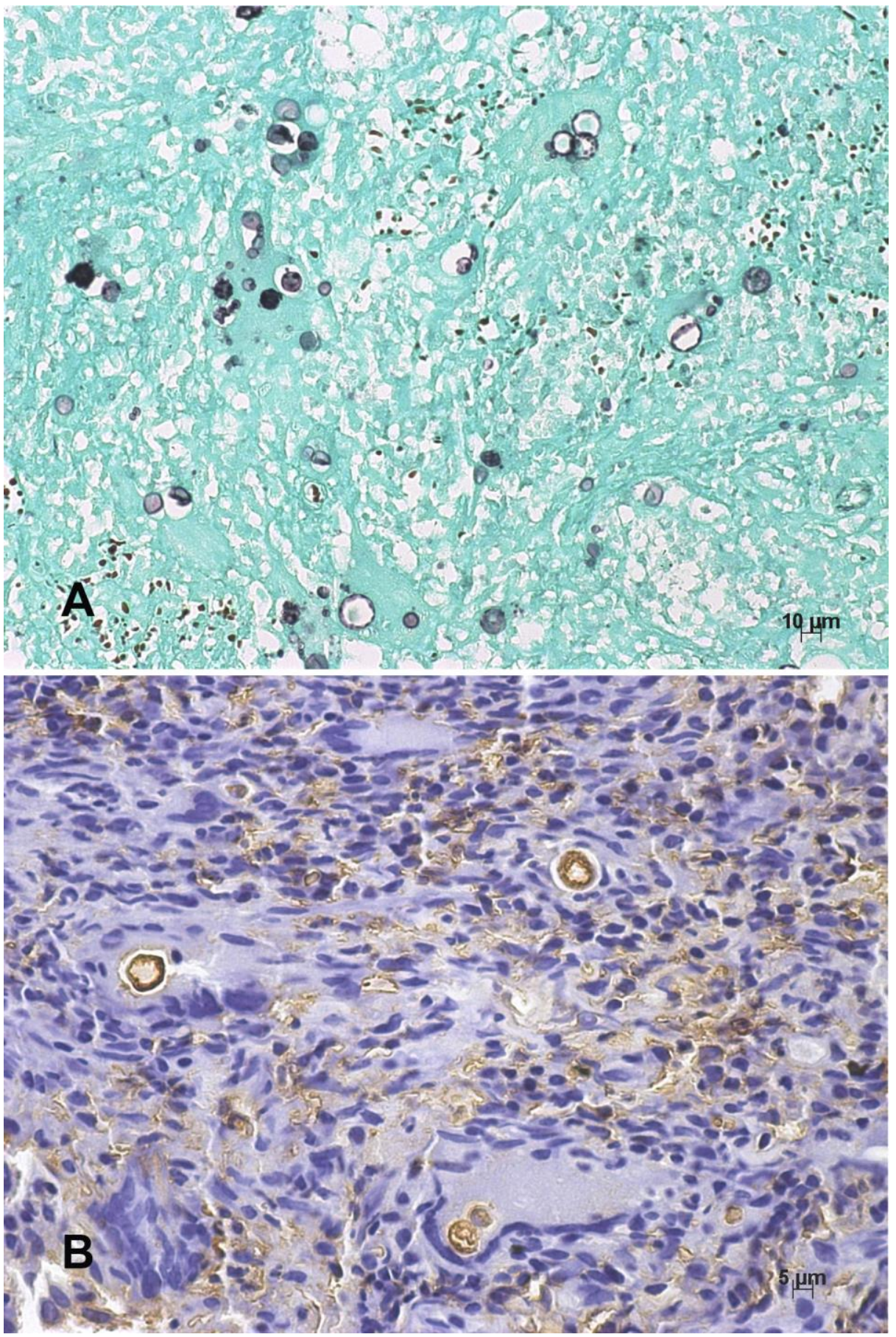

Figura 4. Paracoccidioidomicose - mucosa oral. A - Numerosas Formas fúngicas de tamanho variado evidenciadas pela coloração de Grocott, algumas em aspecto de "roda de leme". B - Formas fúngicas imunomarcadas pelo anticorpo anti - Paracoccidioides brasiliensis. (técnica imuno-histoquímica). 


\section{DIAGNÓSTICO}

O diagnóstico da PCM é relativamente simples e baseado na visualização direta do fungo em material biológico, além da utilização de testes sorológicos específicos (Ferreira, 2009).

As amostras utilizadas no diagnóstico da PCM são, geralmente, obtidas de raspados de lesões cutâneas, biopsias das lesões, aspirado de linfonodos obtidos por punção e visualizadas em microscópio de luz após tratamento com hidróxido de potássio a 10\%, sendo possível observar as leveduras com sua parede birrefringente e a eventual presença de brotamento de células-filhas (Almeida et al., 2003; Ramos-e-Silva e Saraiva, 2008; Ferreira, 2009; Marques, 2012).

Testes sorológicos, como a imunodifusão e o ensaio imunoenzimático (ELISA) modificado para a captura de antígenos, contra-imunoeletroforese, imunofluorescência indireta e o "Western-blot" são utilizados no auxílio para o diagnóstico e para monitoração do tratamento da PCM. Os títulos de anticorpos variam de acordo com a gravidade da doença, sendo mais altos nas formas agudas/sub-agudas e mais baixos na forma crônica. Eventualmente, podem ocorrer resultados falso-positivos com soros de doentes com histoplasmose e aspergilose (Almeida et al.,2003; Shikanai-Yasuda et al., 2006; Ferreira, 2009; Ramos-e-Silva e Saraiva, 2012). 
Exames de imagem auxiliam no diagnóstico do envolvimento pulmonar e outros órgãos (Almeida et al., 2003; Shikanai-Yasuda et al.,2006; Ramos-e-Silva e Saraiva, 2008; Ferreira, 2009; Marques, 2012).

De acordo com Minami (2003), o encontro das formas fúngicas em exame micológico direto ou a partir de biopsias das lesões já é suficiente para indicar o início do tratamento, uma vez que o isolamento do fungo e sua cultura são mais difíceis e demorados.

O exame histopatológico pode fornecer o diagnóstico da doença, quando além da resposta tecidual consistente, formas em leveduras apresentam a gemulação múltipla (roda de leme) característica do gênero Paracoccidioides. O exame histopatológico pode propiciar o diagnóstico da PCM em 96\% dos casos (Moreto et al., 2011).

O emprego da reação de polimerização em cadeia (PCR) acena como uma técnica muito promissora graças a sua alta especificidade e sensibilidade (Ramos-e-Silva e Saraiva, 2008)

Deve-se levar em conta o diagnóstico diferencial com outras doenças, como a leishmaniose nos casos de acometimento de mucosa oral, esporotricose e linfomas devido ao acometimento de linfonodos na PCM (Lupi et al., 2005) 


\section{TRATAMENTO}

A cura espontânea da PCM é pouco comum, com exceção de alguns casos de foco pulmonar exclusivo. O tratamento deve levar em conta o perfil do paciente e a manifestação da doença. Diferente de outros fungos patogênicos, - $P$. brasiliensis é sensível à maioria das drogas antifúngicas, inclusive aos sulfamídicos (Shikanai-Yasuda et al., 2006; Ramos-e-Silva e Saraiva, 2008; Marques, 2012).

O Itraconazol mostra bons resultados no tratamento das formas leves e moderadas, sendo empregado em período variável de acordo com essas formas. Também é empregado o tratamento com sulfametoxazol/ trimetoprim, sendo amplamente empregado no tratamento das lesões em mucosas (Shikanai-Yasuda, 2006; Ferreira, 2009; Marques, 2012).

As formas mais graves são tratadas, em geral com Anfotericina B por via endovenosa levando-se em conta os cuidados necessários na administração dessa droga devido a sua conhecida toxicidade (Shikanai-Yasuda, 2006; Ferreira, 2009; Marques, 2012).

Na impossibilidade de terapia oral, o paciente deve receber o tratamento com Anfotericina B ou sulfametoxazol/trimetoprim por via endovenosa (Shikanai-Yasuda, 2006). 


\section{SISTEMA IMUNE DA PELE E DA MUCOSA ORAL}

O sistema imune da pele e das mucosas tem função de defesa e imunovigilância contra agentes patogênicos microbianos, alergênicos, químicos e físicos (Streilein, 1983). Os queratinócitos, células endoteliais, células de Langerhans e células dendríticas dérmicas integram os elementos celulares da resposta imune inata nos tegumentos. Os linfócitos $\mathrm{T}$ de memória, mas também linfócitos $B$, constituem os elementos celulares da resposta imune adaptativa cutânea (Ochoa et al., 2008).

\subsection{Células dendríticas da pele e mucosa oral}

As células dendríticas são uma população heterogênea de células do sistema imune, componentes da família das células apresentadoras de antígenos (APC), que inclui também linfócitos B e macrófagos (Merad e Manz, 2009). Os precursores dessas células são originados na medula óssea e migram para os tecidos periféricos, onde ali permanecem na forma imatura (Newman e Holly, 2001). 
As células dendríticas (CD) são consideradas profissionais na função de apresentação antigênica, pois também têm capacidade de migrar dos sítios de lesão para os órgãos linfóides, onde apresentam os antígenos captados para linfócitos T "naïve". Desse modo, têm papel fundamental na transição da resposta imune inata para a resposta imune adaptativa (Newman e Holly, 2001; Valladeau e Saeland, 2005).

\subsubsection{Células de Langerhans}

As células de Langerhans (LC) são residentes da pele e mucosa oral normais. Localizam-se principalmente na epiderme e nos epitélios de revestimento de mucosas, sobretudo em sua forma imatura. Constituem cerca de 2 a 4\% da população celular da epiderme (Moll et al., 1993; Valladeau e Saeland, 2005; Chalermsarp e Azuma, 2009).

As LC não são identificadas nos tecidos por colorações de rotina, como a hematoxilina-eosina, sendo necessário o emprego de técnicas específicas para evidenciá-las, como a técnica citoquímica da ATPase e técnicas de imuno-histoquímica (Cutler; Jotwani, 2006). 
As LC expressam em sua membrana marcadores como a molécula CD1a e a langerina (CD207), além de moléculas do antígeno de histocompatibilidade principal (MHC) das classes I e II. Têm capacidade de ser potente célula apresentadora de antígenos (Valladeau e Saeland, 2005). Além disso, as LC têm função na tolerância imunológica, quando em seu estado imaturo, que se modifica quando passam a participar da resposta imune nos sítios de lesão (Novak et al.,2010).

\subsubsection{Células dendríticas dérmicas}

As células dendríticas dérmicas (CDD) foram inicialmente consideradas como uma população celular homogênea que expressa o fator de coagulação XIIla (FXIIla) no seu citoplasma (Cerio et al., 1989).

O nome dendrócito dérmico (DD) foi proposto por Headington (1986). As CDD têm morfologia dendrítica, e além de expressar no citoplasma o FXIlla da coagulação, expressam o antígeno MHC-II e a molécula CD36 (Valladeau e Saeland, 2005).

Os DDFXIlla+ são considerados células dendríticas relacionadas aos monócitos. São CD14+, expressam as moléculas CD209 (DC-SIGN - 
"Dendritic Cell-Specific Intercellular adhesion molecule-3-Grabbing Nonintegrin") e CD163 (Collin et al., 2013). Segundo Zaba et al. (2007) por expressar as moléculas CD163, CD206 e CD209 deveriam de ser considerados macrófagos fixos/residentes da pele normal e não células dendríticas.

De acordo com os experimentos de Ochoa et al. (2008) as CDD compreendem pelo menos dois principais componentes de células com morfologia dendrocítica na derme da pele normal: células dendríticas imaturas que expressam as moléculas CD1, CD11c e CD208 e os macrófagos que expressam as moléculas CD209, CD206, CD163 e CD68. Entretanto, esses autores consideram que ambas populações celulares apresentam características funcionais tanto de macrófagos como de células dendríticas. Sua função fagocítica é comprovada pela capacidade de fagocitar hemossiderina, melanina e bactérias (Altman et al., 1992; Nestle et al., 1998). Por outro lado, têm capacidade de processar antígenos, migrar para os linfonodos e exercer a apresentação antigênica para os linfócitos T "naive" (Nestle et al., 1993; Nestle e Nickoloff, 1995).

As células dendríticas inflamatórias são observadas nos processos inflamatórios da pele e de outros órgãos. Esse componente celular dendrocítico, de acordo com as características predominantes no microambiente, podem induzir resposta imune de perfil Th1 ou Th2. Sua origem parece ser monocítica/macrofágica (Segura et al., 2013; Collin et al., 2013). 
Podemos observar que as células dendríticas são melhor estudadas na pele. Na mucosa oral, por outro lado, os estudos que abordam a população celular dendrocítica são escassos. Os DDFXIIla+ estão presentes na mucosa oral tanto em condições normais quanto em condições reativas. Há um aumento dessa população celular em situações de reatividade quando comparadas ao tecido normal (Regezzi et al., 1992). O estudo das células dendríticas da mucosa oral é considerado como negligenciado e baseado nos dados de pesquisas em outros tecidos (Nudel et al.2011).

10.1.3. Células dendríticas nos processos infecciosos da pele e da mucosa oral

O papel das LC nos mecanismos imunopatológicos de doenças infecciosas que acometem a pele e mucosas tem sido objeto de estudo na literatura (Valladeaud; Saeland, 2005). As LC, além de sua função como APC, podem mesmo ser parasitadas por microorganismos, como o observado na leishmaniose experimental murina (Blanket al. 1993).

$\mathrm{Na}$ PCM as LC na epiderme das lesões cutâneas mostram-se diminuídas em número e morfologicamente alteradas (Gimenez et al., 1987; Pagliari; Sotto, 2003). Entretanto, Sandoval et al. (1996) não observaram o parasitismo das LC pelo fungo, mesmo à análise de lesões cutâneo-mucosas à microscopia eletrônica de transmissão. 
O comportamento das LC maduras (que expressam a molécula CD207) na PCM foi tema de estudo por Pagliari et al. (2011). Essas células mostram-se diminuídas em número na epiderme e ainda mais acentuadamente reduzidas no epitélio de revestimento de mucosa oral das lesões. Por outro lado, células CD207 positivas mostraram-se numerosas em meio às células inflamatórias na lâmina própria da mucosa oral das lesões, principalmente quando a resposta tecidual exibia granulomas frouxos ou ambos os tipos de granulomas (organizados e frouxos). Essas células, segundo os autores, podem representar LC maduras, no processo de migração para o linfonodo, ou mesmo outra população de células dendríticas distinta das LC.

O envolvimento dos DDFXIIla+ nas doenças infecciosas tem sido tema de estudo por diversos autores (Probst-Cousin et al., 1997; Pereira et al., 2008; Simões Quaresma, 2009; de Alvarenga Lira et al.,2015). Na PCM essas células participam da resposta tecidual das lesões cutâneas e estão aumentadas em número quando a resposta tecidual é composta por granulomas bem organizados e frouxos (Pagliari; Sotto, 2003). Exibem interação com o $P$. brasiliensis nos sítios de lesão cutânea (Pagliari; Sotto, 2002). Na cromoblastomicose, participam da resposta tecidual e demonstram antígenos fúngicos (Fonsecaea pedrosol) no seu citoplasma, revelados por técnica imuno-histoquímica de dupla marcação (Sotto et al. 2004). Na leishmaniose cutânea ocorre também a colocalização de formas amastigotas de Leishmania e DDFXIIIa+ (Sotto et al., 2010). Em todas essas situações podemos especular se essa população celular seria somente alvo dos parasitas ou estaria atuando como APC e mesmo como célula efetora frente aos parasitas. 


\subsection{Queratinócito como célula do sistema imune da pele e mucosa oral}

Os queratinócitos são componentes do sistema imune da pele e mucosa oral, podem atuar como células apresentadoras de antígenos facultativas (Nickoloff; Turka, 1993; Nestle et al., 2009) e mesmo fagocitar parasitas em determinadas situações (Blank et al, 1993). Participam dos mecanismos de defesa contra agentes infecciosos (Schröder, 2010).

Na PCM a epiderme e os epitélios de revestimento da mucosa oral mostram-se alterados, frequentemente hiperplásicos e até mesmo com hiperplasia pseudocarcinomatosa (Franco et al., 2006).

A internalização de leveduras do $P$. brasiliensis por células epiteliais foi demonstrada em modelos experimentais "in vitro" (Mendes-Giannini et al, 2008) e por estudo de microscopia eletrônica de lesões de PCM humana (de Brito et al., 1974). A internalização do fungo em células epiteliais é interpretada como possível mecanismo de evasão e proteção do parasita da ação lesiva de fagócitos profissionais, o que possibilitaria a sua disseminação (MendesGiannini et al., 2008). 


\section{CAPÍTULO 4 - MÉTODOS}

\section{MÉTODOS}

\subsection{Casuística}

Foram selecionadas 47 biopsias de lesões de mucosa oral e 52 biopsias de lesões de pele do arquivo do Laboratório de Dermatopatologia da Divisão de Clínica Dermatológica do Hospital das Clínicas da Faculdade de Medicina da Universidade de São Paulo, realizadas no período de 1963 a 1969. Todos os doentes tiveram o diagnóstico clínico de paracoccidioidomicose e demonstraçãode formasfúngicasem levedura, com exoesporulação múltipla inequívoca, nos espécimes de biopsia. Todos os doentes eram procedentes do Estado de São Paulo onde o agente da paracoccidioidomicose é o Paracoccidioides brasiliensis (Theodoro et al., 2012).

O critério para seleção dos casos, além dos já mencionados, foi o tamanho do espécime de biopsia suficiente para a realização dos procedimentos técnicos do estudo.

As biopsias foram classificadas de acordo com o padrão de resposta tecidual ao exame dos cortes corados pelahematoxilina-eosina, sendo estabelecidos três grupos de resposta tecidual (Pagliari; Sotto, 2002): 
- G1-Granulomas bem formados

- $\mathrm{G} 2$ - Granulomas frouxos

- G3 - Granulomas frouxos e bem formados numa mesma amostra

Os pacientes cuja biopsia de pele foi estudada tinham média de idades de 34,75 anos e para os de mucosa oral a média de idades foi de 33,23 anos.

A realização desse trabalho foi aprovada pela Comissão de Ética para Análise de Projetos de Pesquisa - CAPPesq da Diretoria Clínica do Hospital das Clínicas e da Universidade de São Paulo, sob o № 0792/2008 (anexo A).

1.2. Técnica de dupla marcação para demonstração de interação de dendrócitos dérmicos fator XIlla positivos e do Paracoccidioides brasiliensis

O material embebido em parafina foi submetido à microtomia com obtenção de cortes histológicos de quatro $\mu \mathrm{m}$ de espessura, colhidos em lâminas de vidro previamente preparadas com solução adesiva de "3 aminopropyltrietoxy-silane" (Sigma ChemicalCo,código A3648, St. Louis, MO/EUA). 
A seguir, foram desparafinizados em dois banhos de xilol à temperatura ambiente em capela química (20 e 10 minutos respectivamente) e hidratados em cadeia decrescente de etanol (absoluto, 95\% e 70\%) durante cinco minutos com posterior lavagem em água corrente e destilada por dez minutos. Fez-se a exposição antigênica com a solução “Target Retrieval Solution" pH 9,0 (Dako, código S2367, Carpinteria, CA, EUA) em banho-maria a 95ํㅡ por 20 minutos, com posterior lavagem em água corrente por dez minutos e em água destilada por mais cinco minutos. O bloqueio da peroxidase endógena foi feito em câmara escura com três incubações com peróxido de hidrogênio 3\% por dez minutos cada vez. Em seguida, o material foi novamente lavado em água corrente e água destilada por dez minutos cada lavagem. A seguir foi feito bloqueio com leite desnatado (Molico®, Nestlé) 10\% diluído em solução salina tamponada com fosfatos (PBS) $0,01 \mathrm{M}, \mathrm{pH} 7,4$ a $37^{\circ} \mathrm{C}$ por 30 minutos.

A seguir fez-se o bloqueio da fosfatase alcalina endógena com a solução "Dual Endogenous Enzime Block" (Dako, código S2003, Carpinteria, $\mathrm{CA}, \mathrm{EUA}$ ) durante dez minutos em temperatura ambiente.

Procedeu-se, a seguir, a incubação do material com o primeiro anticorpo primário anti-P.brasiliensis obtido no Instituto de Medicina Tropical de São Paulo (Pagliari; Sotto, 2002) diluído 1/300 em PBS 0,01M pH 7,4 acrescido de $1 \%$ de soroalbumina bovina (BSA) "overnight" a $4^{\circ} \mathrm{C}$.

Após a incubação com o primeiro anticorpo primário o material foi submetido a três lavagens com PBS por cinco minutos cada; procedeu-se à incubação com o anticorpo secundário do "kit EnVision ${ }^{\mathrm{TM}}$ G2 System/AP 
Rabbit/Mouse link" (Dako, K5355, Carpinteria, CA, EUA), por 30 minutos a $37^{\circ} \mathrm{C}$.

Os cortes histológicos foram novamente lavados em PBS, como descrito anteriormente e incubados com o polímero potenciador do "kit EnVision $^{\mathrm{TM}}$ G2 System/AP AP Enzyme", por 30 minutos a $37^{\circ} \mathrm{C}$. Após nova lavagem em PBS, a reação foi revelada com solução cromógena "PermaGreen/AP" 1/150 (Diagnostic Biosystems, K52,Pleasanton, CA, EUA)por cinco a 15 minutos, com controle da intensidade da coloração de marcação ao microscópio óptico.

Os cortes histológicos, então, foram novamente lavados em água corrente por cinco minutos e em água destilada por mais cinco minutos e PBS $0,01 \mathrm{M} \mathrm{pH} \mathrm{7,4.}$

Prosseguiu-se com a reação para a demonstração dos dendrócitos com o anticorpo primário anti-FXIIla (Labvision,RB1464-P, Fremont, CA, EUA) $1 / 2700$ em PBS acrescido de $1 \%$ de BSA por uma hora a $37^{\circ} \mathrm{C}$. Após a incubação com o segundo anticorpo primário o material foi submetido a três lavagens com PBS por cinco minutos cada; procedeu-se à incubação com o anticorpo secundário "Novolink ${ }^{\mathrm{TM}}$ Post PrimaryBlock" (Novocastra, 7159, Newcastle upon Tyne, Reino Unido) por 30 minutos a $37^{\circ} \mathrm{C}$. Foram feitas mais três lavagens de cinco minutos cada com PBS e seguiu-se com a incubação com "Novolink ${ }^{\text {TM }}$ Polymer" (Novocastra, 7159,Newcastle upon Tyne, Reino Unido) por 30 minutos a $37^{\circ} \mathrm{C}$. 
A reação foi revelada com 45 mg do cromógeno3' 3 diaminobenzidina (DAB) (Sigma Chemical Co, D5637, St. Louis, MO/EUA)em 100 ml de PBS pH 7,4 e $1,2 \mathrm{ml} \mathrm{H}_{2} \mathrm{O}_{2} 3 \%$ por dois minutos.

Os cortes histológicos foram a seguir lavados em água corrente e destilada, sendo cada lavagem feita por dez minutos, contracorados com hematoxilina de Mayer por dois segundos, lavados em água corrente e secos em estufa a $37^{\circ} \mathrm{C}$. Fez-se a montagem das lâminas com resina Permount (Fisher Scientific,SP15-100, Fair Lawn, NJ, EUA).

Somente as amostras de mucosa oral foram submetidas a esse procedimento técnico, uma vez que a colocalização de $P$. brasiliensis e dendrócitos dérmicos foi anteriormente demonstrada (Pagliari; Sotto, 2002).

\subsection{Técnica de dupla marcação de células de Langerhans (CD207)} e do Paracoccidioides brasiliensis

Os procedimentos iniciais até a incubação com o segundo anticorpo primário utilizado foram semelhantes aos descritos no item 1.2.

Prosseguiu-se a reação com a incubação do material com o segundo anticorpo primário anti-Langerin (CD207) (Novocastra, clone 12D6, Newcastle upon Tyne, Reino Unido) diluído 1/100 em PBS acrescido de 1\% de BSA, por uma hora a $37^{\circ} \mathrm{C}$. 
Após a incubação com o segundo anticorpo primário o material foi submetido a três lavagens com PBS por cinco minutos cada; procedeu-se à incubação com o anticorpo secundário "Novolink ${ }^{\mathrm{TM}}$ Post PrimaryBlock" (por 30 minutos a $37^{\circ} \mathrm{C}$. Foram feitas mais três lavagens de cinco minutos com PBS e seguidas de incubação com o“Novolink ${ }^{\mathrm{TM}}$ Polymer" por 30 minutos a $37^{\circ} \mathrm{C}$.

Fez-se a revelação dos sítios de reação com 45 mg de DAB em $100 \mathrm{ml}$ de PBS pH 7,4 e $1,2 \mathrm{ml} \mathrm{H}_{2} \mathrm{O}_{2} 3 \%$ por cinco minutos.

Após lavagens fez-se a contracoloração e montagem dos cortes histológicos com resina e lamínula de vidro como o descrito no item 1.2.

\subsection{Técnica de dupla marcação de queratinócitos com anticorpo} AE1/AE3 e do Paracoccidioides brasiliensis

Os procedimentos desde a desparafinização das lâminas até a fase de bloqueio de proteínas inespecíficas foi realizada como o descrito no item 1.2.

A reação prosseguiu com incubação do primeiro anticorpo primário AE1/AE3 (anti-panqueratina) (NCL-CL-AE1/AE3, Novocastra, NewcastleuponTyne, Reino Unido) diluído a 1/400 em PBS e 1\% de BSA "overnight" a $4^{\circ} \mathrm{C}$. Após a incubação com o segundo anticorpo primário o material foi submetido a três lavagens com PBS por cinco minutos cada; a reação prosseguiu com incubação com o "kit" de detecção "LSAB BiotinylatedLink" (Dako, K0690, Carpinteria, CA, EUA) por 30 minutos a $37^{\circ} \mathrm{C}$. Foram 
realizadas mais três lavagens de cinco minutos cada com PBS seguidas da incubação com "LSAB Streptavidin HRP" (Dako, K0690, Carpinteria, CA, EUA) por 30 minutos a $37^{\circ} \mathrm{C}$.

A reação foi revelada com cromógeno DAB, 45 mg em 100 ml PBS pH $7,4+1,2 \mathrm{ml} \mathrm{H} \mathrm{O}_{2} 3 \%$ por cinco minutos.

Fez-se a seguir o bloqueio da fosfatase alcalina endógena com "Dual Endogenous Enzime Block" (Dako, S2003, Carpinteria, CA, EUA) durante dez minutos em temperatura ambiente. A incubação com o segundo anticorpo primário anti-P.brasiliensis e demais procedimentos foram como os descritos no item 1.2. Entretanto, nessa reação foi utilizado o cromógeno "PermaBlue/AP" (DiagnosticBioSystems, K051, Pleasanton, CA, EUA).

\subsection{Técnica de dupla marcação por imunofluorescência dos queratinócitos com 0 anticorpo anti-AE1/AE3 e anticorpo anti- $P$. brasiliensis e observação no microscópio confocal a laser}

Sete biopsias de pele e uma de mucosa oral que apresentaram positividade indubitável para a reação de dupla marcação por imunohistoquímica com os anticorpos citados no item 1.5 foram submetidos à técnica de imunofluorescência e microscopia confocal a laser.

Cortes histológicos de quatro $\mu \mathrm{m}$ de espessura, colhidos em lâminas de vidro previamente preparadas com solução adesiva de 3 amino- 
propyltrietoxy-silane (Sigma Chemical Co, A3648, St. Louis, MO/EUA,)foram desparafinizados em dois banhos de xilol a temperatura ambiente em capela química, sendo um por 20 minutos e o outro por dez minutos; posteriormente foram hidratados em cadeia decrescente de etanol (absoluto, 95\% e 70\%) durante cinco minutos cada banho com posterior lavagem em água corrente e destilada por dez minutos cada lavagem. A seguir fez-se a exposição antigênica com a solução "Target Retrieval Solution" pH 9,0 (Dako, S2367, Carpinteria, CA, EUA) em banho-maria a 95ํㅡ por 20 minutos, com posterior lavagem em água corrente por dez minutos e em água destilada por mais cinco minutos. A seguir o bloqueio de proteínas inespecíficas foi realizado com PBS e $1 \%$ BSA durante 30 minutos em temperatura ambiente.

Os procedimentos iniciais e de exposição antigênica foram realizados como no item 1.2.

Fez-se, a seguir, a incubação dos cortes histológicos com os anticorpos AE1/AE3 e anti-P.brasiliensis, ambos diluídos a 1/250 em PBS acrescido de $1 \%$ de BSA, num mesmo frasco, durante dois dias a 4ํㅡ. Após esse período o material foi submetido a três lavagens com PBS, por cinco minutos cada.

Em seguida fez-se a incubação com o conjugados fluorescentes anticamundongo produzido em burro (AlexaFluor ${ }^{\circledR}$ 546, Invitrogen,Carlsbad, CA, EUA) e anti-coelho produzido em cabra (AlexaFluor® 488 Invitrogen,Carlsbad, CA, EUA) diluídos 1/250 em PBS 0,01M pH 7,4 acrescido de 1\% de BSA, além do DAPI (“4',6-Diamidino-2-Phenylindole, Dihydrochloride”) (Invitrogen, D1306, Carlsbad, CA, EUA) diluído a 1/100 em PBS 0,01M pH 7,4 acrescido de 
$1 \%$ de BSA. Todos esses reagentes foram colocados no mesmo frasco, onde os cortes histológicos permaneceram durante duas horas ao abrigo da luz e à temperatura de $37^{\circ} \mathrm{C}$. Em seguida o material foi lavado por três vezes com PBS $0,01 \mathrm{M}$. As lâminas foram montadas com glicerina diluída a 50\% em PBS 0,01M pH 7,4 e cobertas com lamínulas de vidro. O material foi mantido protegido da luz em geladeira $\left(4^{\circ} \mathrm{C}\right)$ até ser analisado ao microscópio de fluorescência confocal a laser (Sistema confocal ZEISS LSM 510 Meta / UV) do Núcleo de Microscopia Confocal/Fluorescência da Rede Multiusuários do Sistema FMUSP/HC-FMUSP.

Todas as reações foram realizadas com controles teciduais sabidamente positivos (fragmento de dermatofibroma para o fator XIIla, biopsia de linfonodo com paracoccidioidomicose e pele dentro dos limites da normalidade para os anticorpos CD207 e AE1-AE3). Os controles negativos das reações foram obtidos pela omissão dos respectivos anticorpos primários que foram substituídos por anticorpos isotípicos não reagentes ou PBS, durante os procedimentos técnicos.

As amostras foram consideradas positivas para a colocalização quando as estruturas fúngicas foram observadas de modo inequívoco no citoplasma dos elementos celulares estudados através das técnicas de dupla marcação imunoenzimáticas e de imunofluorescência. 
2. ANÁLISE ESTATÍSTICA DOS RESULTADOS

As frequências dos casos de mucosa oral com colocalização de células fator Xllla+ e do P. brasiliensis e de biopsias de pele e mucosa oral com colocalização do fungo com queratinócitos foram comparadas de acordo com o grupo de resposta tecidual observada. Fez-se a comparação pelo teste exato de Fisher. Considerou-se significante o valor de $p \leq 0,05$. 


\section{CAPÍTULO 5 - RESULTADOS}

\section{ANÁLISE HISTOPATOLÓGICA}

Treze das quarenta e sete amostras de mucosa oral apresentaram resposta tecidual caracterizada por granulomas bem formados (G1), 19 exibiam formação de granulomas frouxos (G2) e 15 presença de ambos os tipos de granulomas (G3) na lâmina própria. Na pele 11 amostras mostravam granulomas bem formados (G1), 22 a formação de granulomas frouxos (G2) e 19 a presença de ambos os tipos de granulomas (G3) na derme.

Tanto nas amostras de mucosa oral como nas de pele foi frequente a acantose irregular do epitélio de mucosa/epiderme onde eram observados granulomas intra-epiteliais. Todas as amostras exibiram formas fúngicas em levedura, de tamanho variável, com exoesporulação múltipla. Apresentavam-se no citoplasma de macrófagos multinucleados e nos focos de exsudação neutrofílica dos granulomas de centro supurado. Os fungos foram melhor evidenciados pela coloração de Grocott. No grupo G2, tanto de espécimes de mucosa como de pele havia uma maior quantidade de estruturas fúngicas que nos grupos de resposta tecidual G1 e G3. 
2. DEMONSTRAÇÃO DE COLOCALIZAÇÃO DO P. BRASILIENSIS NO CITOPLASMA DE DENDRÓCITOS DÉRMICOS FATOR XIIIa+

A presença de leveduras do $P$. brasiliensis no citoplasma de dendrócitos dérmicos foi observada em $42 \%$ das amostras de mucosa oral. Os dendrócitos dérmicos mostraram-se abundantes, com citoplasma amplo, dendritos proeminentes e se localizavam ao redor dos granulomas e por entre as células do infiltrado inflamatório (figura 5). 


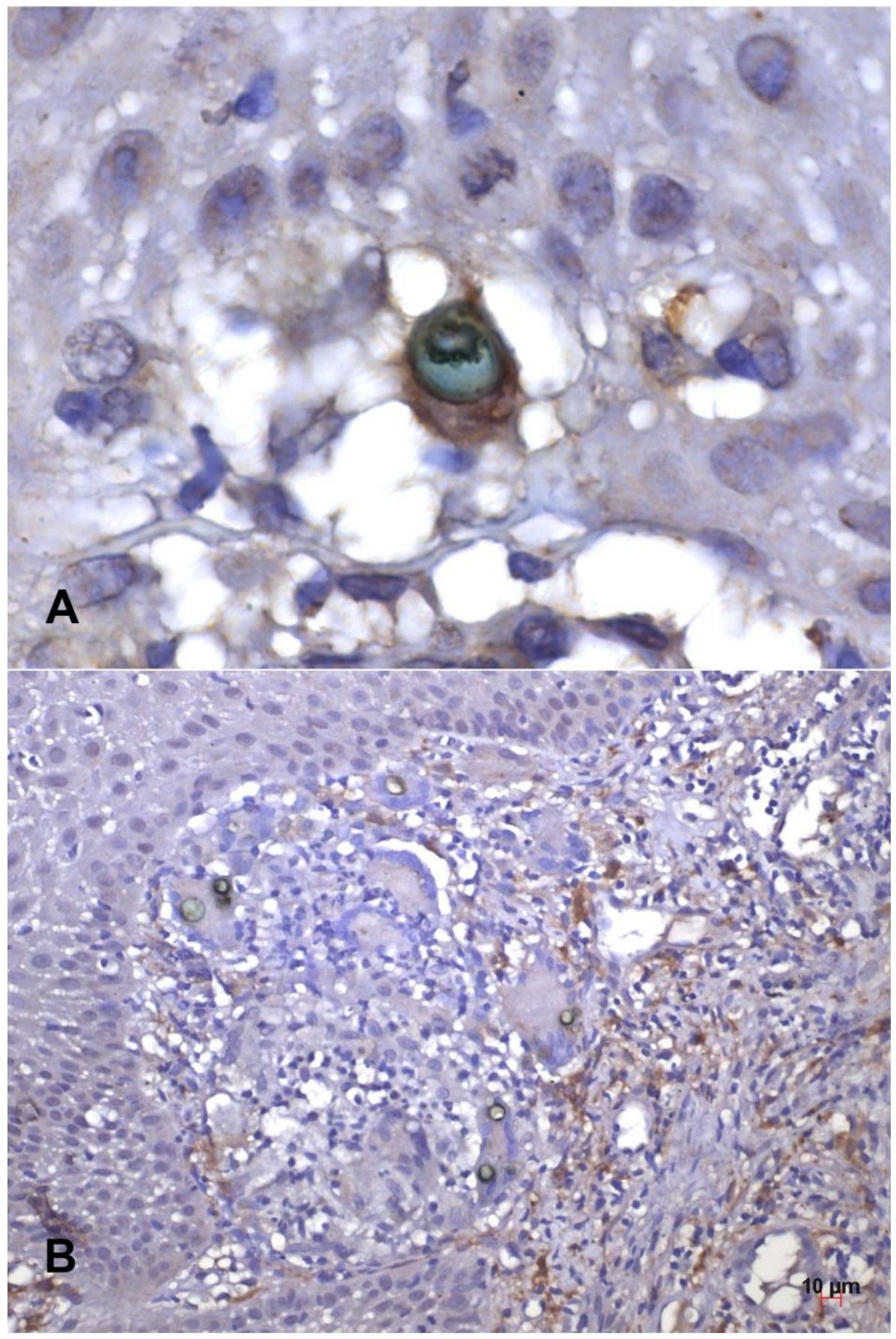

Figura 5. Paracoccidioidomicose: A - Levedura do P. brasiliensis no citoplasma de dendrócito dérmico na lâmina própria superficial de mucosa oral. B - Dendrócitos dérmicos abundantes e dispostos em torno de granuloma. Presença de leveduras no citoplasma de macrófagos multinucleados que compõem o granuloma. Técnica de imuno-histoquímica com os anticorpos antiFXIIla (marrom) e anti-P. brasiliensis (verde). 


\section{CÉLULAS DE LANGERHANS IMUNOMARCADAS PELO ANTICORPO CD207 (LANGERINA)}

As Células de Langerhans apresentaram-se distribuídas no epitélio/epiderme das 47 biopsias de lesões de mucosa oral e 52 de pele. Eram escassas, irregularmente distribuídas e exibiram dendritos irregulares e curtos (figura 6A). Essas células foram também observadas esparsas por entre 0 infiltrado inflamatório da derme e córion em 29/52 amostras de pele e 28/47 amostras de mucosa oral (figura 6B). Em nenhuma das amostras observou-se a colocalização de estruturas fúngicas no citoplasma das células imunomarcadas com o anticorpo CD207. 

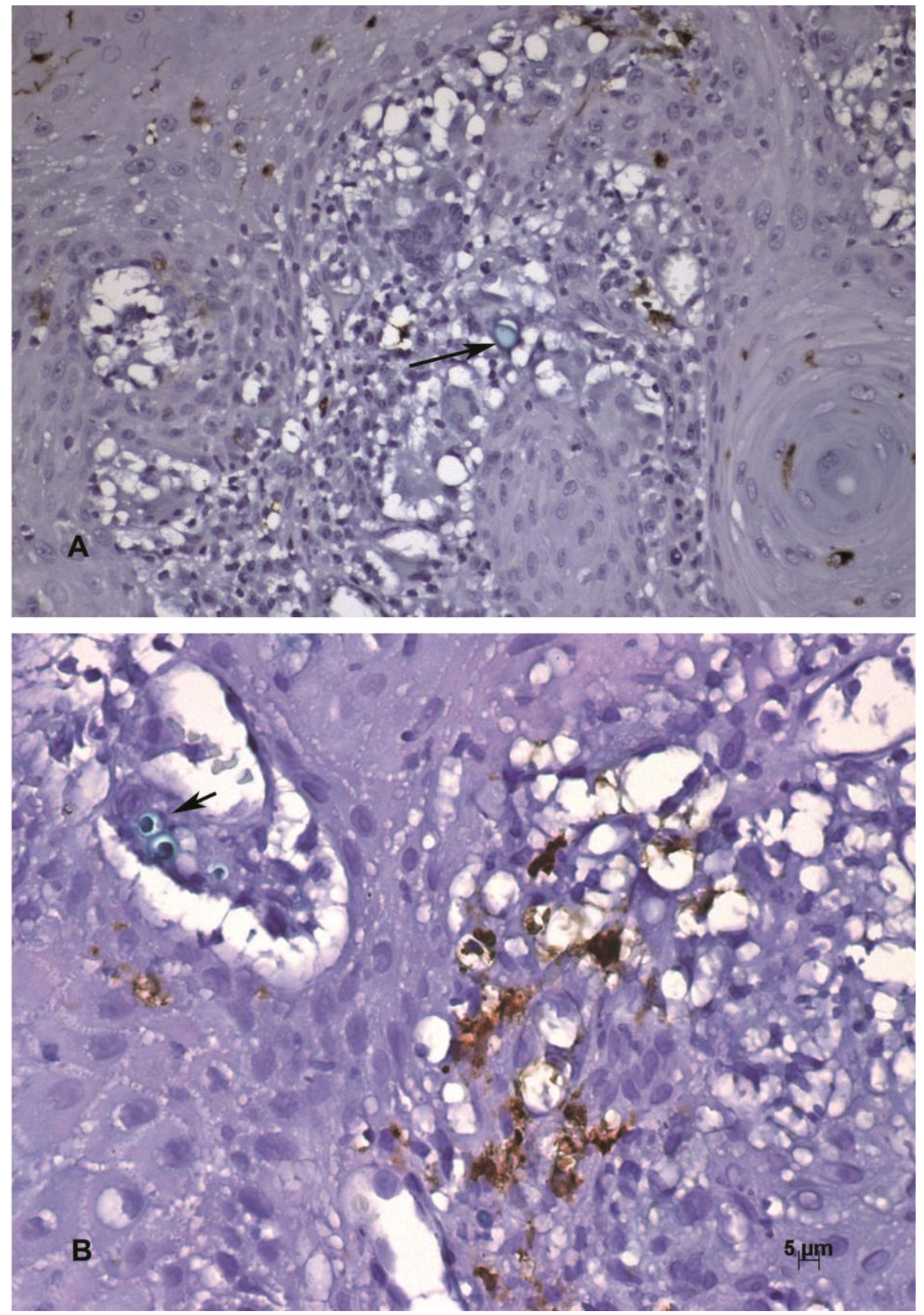

Figura 6. Paracoccidioidomicose: A - Células de Langerhans na camada espinhosa do epitélio de mucosa oral e levedura na lâmina própria superficial (seta). B - Presença de células de Langherans entre células inflamatórias na lâmina própria de mucosa oral e leveduras no citoplasma de macrófago multinucleado (seta). Técnica imuno-histoquímica de dupla marcação com os anticorpos anti-CD207/Langerina (marrom) e anti-P. brasiliensis (verde). 
4. DEMONSTRAÇÃO DE COLOCALIZAÇÃO DO P. BRASILIENSIS NO CITOPLASMA DE QUERATINÓCITOS PELAS TÉCNICAS IMUNOENZIMÁTICA E DE IMUNOFLUORESCÊNCIA

Em 28/47 amostras de mucosa oral e 28/52 de pele observou-se a presença do fungo no citoplasma de queratinócitos (figura 7).

Todas as amostras de pele (sete) e a de mucosa oral submetidas à técnica de imunofluorescência e ao exame de microscopia confocal a laser demonstraram a presença de leveduras no citoplasma de queratinócitos da epiderme e do epitélio de mucosa (figura $8 \mathrm{~A}$ e B). Material antigênico do $P$. brasiliensis foi observado, focalmente, no espaço intercelular dos epitélios (figura 8C e D). 

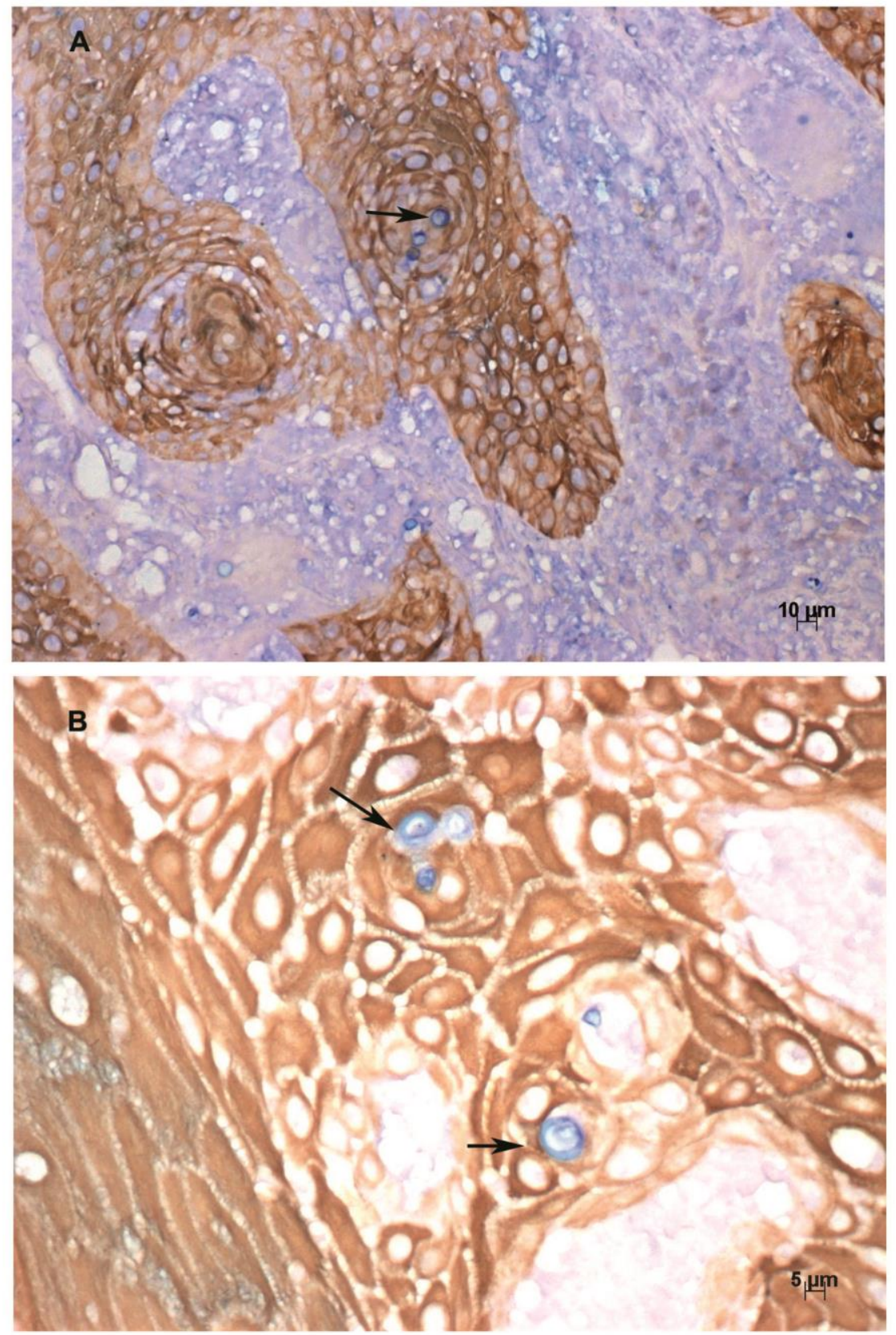

Figura 7. Paracoccidioidomicose: Leveduras do Paracoccidioides brasiliensis no citoplasma de queratinócitos do epitélio de mucosa oral (A) e da pele (B). Notar levedura no interior das células de interesse (setas). Técnica imunohistoquímica de dupla marcação com os anticorpos AE1/AE3 (marrom) e antiP. brasiliensis (azul). 


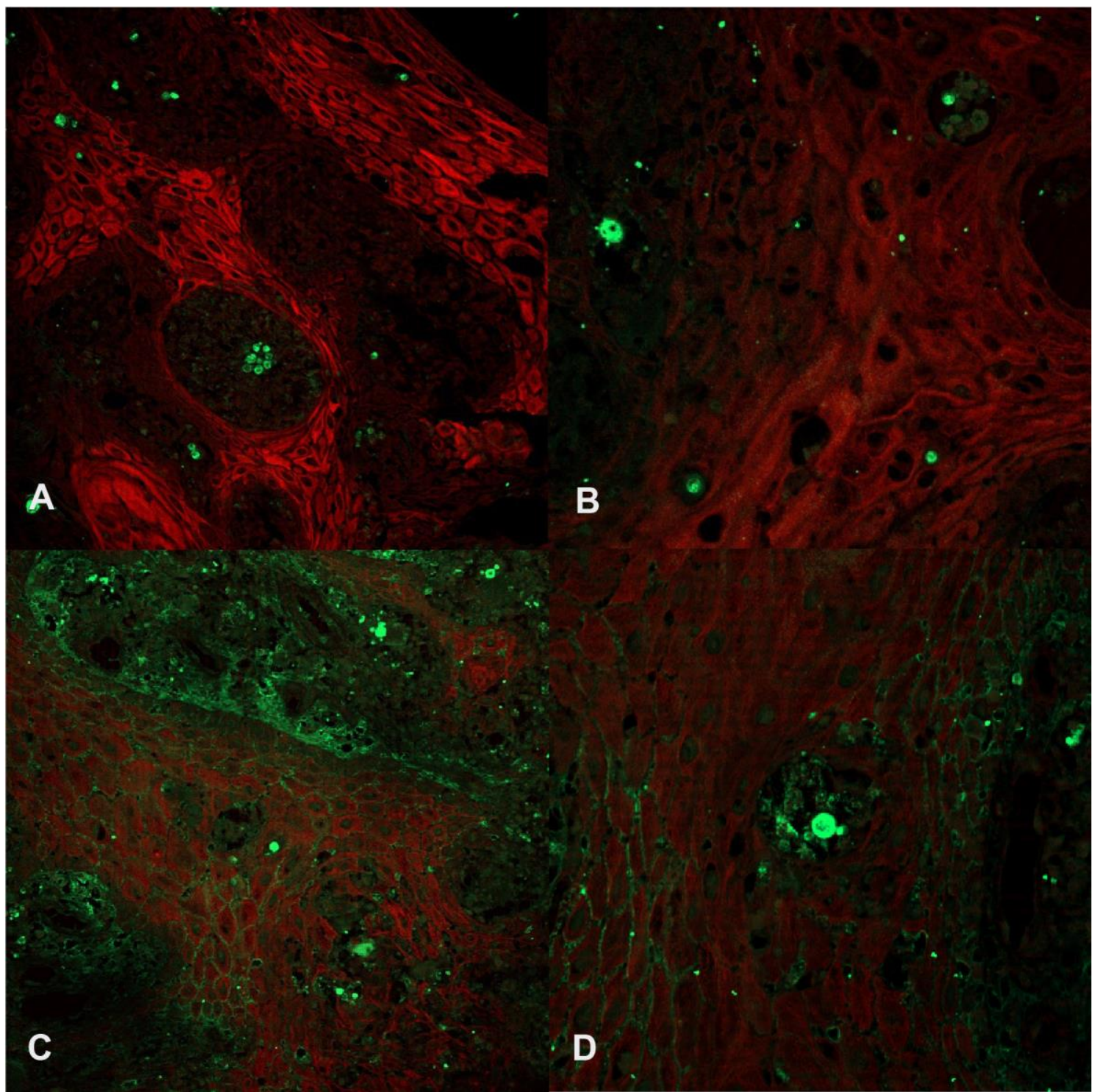

Figura 8. Paracoccidioidomicose: A e B - Presença de leveduras com exoesporulação múltipla em microabscesso epitelial e no citoplasma de queratinócitos. C e D - Depósitos fluorescentes de material antigênico no espaço intercelular epitelial. Técnica de imunofluorescência de dupla marcação com os anticorpos AE1/AE3 (vermelho) e anti- $P$. brasiliensis (verde). Análise por microscopia confocal a laser. 


\section{ANÁLISE ESTATÍSTICA DOS RESULTADOS}

O número de amostras de mucosa oral com resposta tecidual de tipo G2 (granulomas frouxos) com presença de leveduras do $P$. brasiliensis no citoplasma de dendrócitos dérmicos foi maior que o de amostras com resposta tecidual de tipo G1 (granulomas bem organizados) e G3 (resposta tecidual com granulomas bem organizados e frouxos). Ver tabela 1.

Tabela 1. Comparação do número de amostras de mucosa oral com leveduras de Paracoccidioides brasiliensis no citoplasma de dendrócitos dérmicos Fator XIIla+

Resposta Amostras positivas Amostrasnegativas $\quad$ Valor de $p^{\star}$

tecidual

G1

6/13 (46\%)

7/13 (54\%)

0.0003

(G2 vs G1)

G2

$14 / 19(63 \%)$

$5 / 19(37 \%)$

0.003

(G2 vs G3)

G3

$5 / 15(67 \%)$

10/15 (33\%)

$>0.05$

(G3 vs G1)

G1 -granulomas bem organizados; G2 - granulomas frouxos; G3 - ambos os tipos de granuloma. *Teste exato de Fisher. 
O número de amostras de mucosa oral e pele com formas fúngicas no citoplasma de queratinócitos, classificadas de acordo com o tipo de resposta tecidual, não diferiu (tabela 2).

Tabela 2. Comparação do número de amostras de mucosa oral e pele com presença de leveduras do Paracoccidioides brasiliensis no citoplasma de queratinócitos.

Amostras de mucosa oral $(n=47)$

$\begin{array}{lll}\begin{array}{l}\text { Resposta } \\ \text { tecidual }\end{array} & \text { Amostraspositivas } & \text { Amostrasnegativas } \\ \text { G1 } & 6 / 13(46 \%) & 7 / 13(54 \%) \\ \text { G2 } & 12 / 19(63 \%) & 7 / 19(37 \%) \\ \text { G3 } & 10 / 15(67 \%) & 5 / 15(33 \%)\end{array}$

Amostras de pele $(n=52)$ Amostraspositivas Amostrasnegativas
G1
$5 / 11(45 \%)$
$6 / 11(55 \%)$
G2
$11 / 22(50 \%)$
$11 / 22(50 \%)$
G3
$12 / 19(63 \%)$
$7 / 19(37 \%)$

G1 -granulomas bem organizados; G2 - granulomas frouxos; G3 - ambos os tipos de granuloma. Sem diferenças entre os grupos. Teste exato de Fisher. 


\section{CAPÍTULO 6 - DISCUSSÃO}

Demonstramos o parasitismo (ou interação) de DDFXIIla+ pelo (ou com) o P.brasiliensis em 42\% (20/47) das biopsias de mucosa oral de doentes com PCM. O parasitismo de DDFXIIla+ foi observado em $40 \%$ de biopsias de lesões de pele de PCM (Pagliari e Sotto, 2002).

Os dendrócitos dérmicos estão envolvidos na patogenia de outras doenças infecciosas. Nas lesões de pele da cromoblastomicose mostram-se abundantes e hipertróficos e exibem material antigênico do agente fúngico em seu citoplasma. Entretanto, a frequência de DDFXIIla+ com evidências de colocalização de antígenos fúngicos nessa micose cutânea (5/18 casos) é menor que na PCM, além disso, nesse trabalho Sotto et al. (2004) não observaram leveduras no citoplasma de dendrócitos, mas tão somente material antigênico fúngico pela técnicaimuno-histoquímica empregada. Nas lesões de pele da leishmaniose tegumentar também foi demonstrado o parasitismo dos DDFXIIla+ por formas amastigotas de Leishmania (Sotto et al., 2010).

O dendrócitos dérmicos são células que exibem função fagocítica e de apresentação antigênica (Altman et al., 1992; Nestle et al., 1998). Considerando os resultados por nós obtidos podemos especular se esse grupo celular atuaria como células apresentadoras de antígenos nas lesões tegumentares da PCM, ou somente, como célula alvo do fungo. 
Além da demonstração do parasitismo, ou interação, de dendrócitos dérmicos nas lesões de mucosa, tivemos como objetivo verificar se haveria diferenças na frequência de colocalização de DDFXIIla+ e o fungo, de acordo com o tipo de resposta tecidual observada, uma vez que, os três tipos de resposta tecidual (granulomas bem organizados, granulomas frouxos e lesões com os dois tipos de granulomas) apresentam diferenças nos perfis de citocinas predominantes (Pagliari e Sotto, 2003). Demonstramos que o grupo de biopsias caracterizadas pela presença de granulomas frouxos e pouco organizados apresentou maior frequência de dendrócitos com colocalização de formas em levedura do $P$. Brasiliensis do que o grupo com resposta granulomatosa melhor organizada $(p=0,0003)$ e do que o grupo de lesões de mucosa oral com resposta tecidual com granulomas bem organizados e frouxos $(p=0.003)$. Esses resultados podem estar relacionados com o fato que na resposta tecidual com granulomas frouxos, pouco organizados, o número de fungos é maior, além disso, essa resposta tecidual é caracterizada por perfil de citocinas de padrão Th2 (Pagliari e Sotto, 2003).

Não observamos colocalização do $P$. Brasiliensis, ou seus antígenos, com as LC imunomarcadas com o anticorpo CD207, tanto nas biopsias de mucosa oral como nas de pele. Esse resultado está de acordo com o observado por Sandoval et al. (1996). Esses autores também não demonstraram leveduras do fungo ou seu material antigênico no citoplasma das LC quando estudaram biopsias de pele e mucosa da PCM humana, por técnica de microscopia eletrônica. As LC são capazes de fagocitar/internalizar partículas de cerca de 0,5 a 1,0 micrômetros, mas a capacidade dessas células 
de internalizar partículas maiores é reduzida (Valladeau e Saeland, 2005). Talvez por essa razão que em nosso trabalho, assim como no de Sandoval et al. (1996), não tenhamos demonstrado a colocalização do $P$. brasiliensis com essa população de $C D$ da pele e mucosa oral. Por outro lado, células dendríticas imunomarcadas pela proteína S100 (outro marcador de LC) presentes na derme de lesões cutâneas da cromoblastomicose exibiram o antígeno do agente fúngico, embora em apenas três de dezoito casos avaliados por Sotto et al. (2004).

Em nosso trabalho, as LC imumonarcadas pelo anticorpo CD207 apresentaram-se aparentemente diminuídas em número e com alterações tróficas como dendritos irregulares e curtos tanto no epitélio de mucosa oral como na epiderme. As LC também se apresentaram esparsas, por entre as células do infiltrado inflamatório da derme e lâmina própria da mucosa. Outros estudos também demonstraram essas mesmas alterações das LC nas lesões tegumentares da PCM (Gimenez et al, 1987; Pagliari e Sotto, 2003; Pagliari et al. 2011a). A redução de LC nos epitélios, assim como as alterações tróficas que apresentam nas lesões tegumentares da PCM, foram interpretadas como decorrentes da possível ação de fatores secretados pelo $P$. brasiliensis nos sítios de lesão. Essa ação do fungo poderia estar relacionada com as alterações da imunidade mediada por células na infecção (Gimenez et al., 1987).

Demonstramos que $60 \%$ (28/47 casos) das biopsias de mucosa oral e 54\% (28/52) das biopsias de pele de PCM apresentavam colocalização do fungo com queratinócitos. Entretanto, não houve diferenças quanto a 
frequência dessa característica nos três grupos de resposta tecidual, tanto na mucosa oral como na pele.

De Brito et al. (1973) demonstraram, através de estudo de microscopia eletrônica de transmissão, o parasitismo de queratinócitos em lesões de mucosa e pele da PCM. Esses autores consideraram que o parasitismo de queratinócitos representaria um outro mecanismo de infecção na PCM humana. A infecção de queratinócitos ocorre através da forma em levedura do fungo, o que é diferente da infecção primária que se dá através da inalação de formas conídio/micelianas que invadem o pulmão (Franco et al., 2006).

A observação de material antigênico do $P$. brasiliensis no espaço intercelular dos epitélios da mucosa oral e pele foi interessante e confirmado pele técnica de imunofluorescência com exame confocal a laser. Aspecto semelhante foi observado por Sandoval et al. (1996). O material antigênico do fungo poderia ser interpretado como mais um fator de dano lesivo aos epitélios na PCM, ou mesmo indutor dos aspectos hiperplásicos frequentemente observados na resposta tecidual tegumentar dessa micose.

O parasitismo de queratinócitos pode representar um mecanismo de evasão do fungo da ação lesiva das células da resposta inflamatória/imunológica nos sítios de lesão (Mendes-Giannini et al., 2008), ou mesmo um mecanismo de imunotolerância ao fungo (da Silva et al., 2011). Por outro lado, podemos sugerir que a presença de leveduras do $P$. brasiliensis nos queratinócitos da epiderme e epitélio de mucosa das lesões de PCM é relacionada à atividade dos queratinócitos como células apresentadoras de antígenos (Nickoloff et al., 1993; Nestle et al., 2009). Os queratinócitos estão 
envolvidos na resposta imune frente a patógenos (Schröder, 2010). Expressam receptores para uma grande variedade de componentes de patógenos e produzem quimiocinas e citocinas em resposta aos estímulos patogênicos (Kuo et al., 2013; Heath e Carbone, 2013).

$\mathrm{Na}$ literatura existe discussão se as LC atuariam sempre de modo eficiente induzindo uma resposta imune protetora frente aos agentes patogênicos (Asahina et al., 2006). Com base nos resultados obtidos nesse trabalho podemos sugerir que nas lesões de pele e mucosa oral da PCM os dendrócitos dérmicos e os queratinócitos poderiam atuar no reconhecimento e apresentação antigênica do agente fúngico, para suprir uma provável alteração funcional das células de Langherans. 


\section{CAPÍTULO 7 - CONCLUSÕES}

1. Ocorre a interação entre o Paracoccidioides brasiliensis e os DDFXIIla+ das lesões de mucosa oral na paracoccidioidomicose humana.

2. As células de Langerhans das lesões de mucosa oral e pele da paracoccidioidomicose humana não apresentam colocalização com leveduras ou antígenos do Paracoccidioides brasiliensis.

3. A colocalização de leveduras do Paracoccidioides brasiliensis com DDFXIIIa+ na mucosa oral é mais frequentemente observada quando a resposta tecidual é composta por granulomas epitelioides pouco organizados ou frouxos.

4. O parasitismo de queratinócitos pelo Paracoccidioides brasiliensis foi observado tanto nas lesões de mucosa oral como nas de pele e não diferiu quanto às características da resposta tecidual nos sítios de lesão.

Os resultados obtidos sugerem que, nos sítios de lesão tegumentar da paracoccidioidomicose humana, os dendrócitos dérmicos e queratinócitos atuariam no reconhecimento e apresentação antigênica do Paracoccidioides brasiliensis, para suprir provável alteração funcional das células de Langerhans. 


\section{CAPÍTULO 8 - SUGESTÕES PARA TRABALHOS FUTUROS}

Nesse trabalho observamos parasitismo de queratinócitos em $60 \%$ das biopsias de mucosa oral e $54 \%$ das biopsias de pele. O parasitismo de queratinócitos pode representar um mecanismo de evasão do fungo da ação lesiva das células da resposta inflamatória/imunológica nos sítios de lesão (Mendes-Giannini et al., 2008), ou mesmo um mecanismo de imunotolerância ao fungo (da Silva et al., 2011). Por outro lado, a presença de leveduras do $P$. brasiliensis nos queratinócitos da epiderme e epitélio de mucosa das lesões de PCM pode ser relacionada à atividade dos queratinócitos como células apresentadoras de antígenos (Nickoloff et al., 1993; Nestle et al., 2009). Os queratinócitos estão envolvidos na resposta imune frente a patógenos (Schröder, 2010). Expressam receptores para uma grande variedade de componentes de patógenos e produzem quimiocinas e citocinas em resposta aos estímulos patogênicos (Kuo et al., 2013; Heath e Carbone, 2013).

A interação dos fungos com células hospedeiras, inclusive as epiteliais, faz-se através do reconhecimento dos padrões moleculares associados a patógenos (PAMPS) e padrões moleculares associados a dano (DAMPS), pelos receptores de reconhecimento de padrões (PRR). Os principais receptores de reconhecimento de padrões das células epiteliais nas micoses são os receptores tipo "toll" (TLR), dectinas 1 e 2, "DC-specific ICAM3-grabbing non-integrin" (DC-SIGN), receptores de manose e galectina-3. Os TLRs e as dectinas ativam múltiplos caminhos intracelulares após a ligação com PAMPS 
dos fungos, que incluem as beta glucanas, quitina, mananas e ácidos nucléicos fúngicos (Romani, 2011).

Existem poucos trabalhos que enfocam a interação do $P$. brasiliensis com células epiteliais e, emparticular com o queratinócito. A maioria deles são estudos "in vitro" ou em modelos experimentais (Mendes-Giannini et al., 2004; Mendes-Giannini et al., 2005; Silva et al., 2011). Os trabalhos desses autores enfocaram as alterações estruturais da célula hospedeira, em particular as alterações de seu citoesqueleto quando do parasitismo pelo $P$. brasiliensis.

Poucos são os trabalhos experimentais que abordam o papel dos TLRs nessa micose, dentre eles TLR 2, 4 e 9 (Calich et al., 2008; Bonfim et al., 2009: Menino et al., 2013). Na PCM humana encontramos somente o trabalho dede Araujo et al. (2015) que, entre outros fatores, verificou a expressão de TLR 2 e 4 pelas células macrofágicas nas lesões de mucosa oral da PCM. Os autores, entretanto, não focaram nesse trabalho a expressão desses receptores de reconhecimento pelos queratinócitos das lesões.

Os TLR estão também envolvidos na expressão de elementos das junções de tipo "tight" dos epitélios. A supra-expressão de TLR 2 e 4 induz a infra-regulação das claudinas 7 e 10, elementos juncionais importantes na manutenção da integridade de barreira dos epitélios (Clarke et al., 2011).

Com base nesses dados da literatura e no frequente parasitismo de queratinócitos observado no nosso trabalho, tanto nas lesões mucosas como cutâneas, acreditamos ser interessante enfocar futuramente a avaliação da expressão de TLR e de claudinas nas lesões tegumentares da PCM humana, 
como possível contribuição para o melhor entendimento da relação parasitahospedeiro nessa micose. 


\section{CAPÍTULO 9 - REFERÊNCIAS}

\section{REFERÊNCIAS}

1. Almeida OP, Junior JJ, Scully C. Paracoccidioidomycosis of the mouth: an emerging deep mycosis.Crit Rev Oral Biol Med 2003;14:268-74.

2. Altman DA, Fivenson DP, Lee MW. Minocycline hyperpigmentation: model for in situ phagocytic activity of factor XIlla positive dermal dendrocytes.JCutanPathol. 1992;19:340-5.

3. Asahina A, Tamaki K. Role of Langerhans cells in cutaneous protective: is the reappraisal necessary? J Dermatol Sci. 2006; 44:1-9.

4. Blank C, Fuchs H, Rappersberger K, Röllinghoff M, Moll H. Parasitism of epidermal Langerhans cells in experimental cutaneous leishmaniasis with Leishmania major. J Infect Dis. 1993;167:418-25.

5. Bocca AL, Amaral AC, Teixeira MM, Sato PK, Shikanai-Yasuda MA, Felipe MSS.Paracoccicioidomycosis: eco-epidemiology, taxonomy and clinical and therapeutic issues. Future Microbiol.2013; 8:1177-1191.

8. Bocca AL, Silva MF, Silva CL et al. Macrophage expression of class II major histocompatibility complex gene products in Paracoccidioidesbrasiliensis-infected mice. Am J Trop Med Hyg. 1999; $61: 280-7$.

9. Bonfim CV, Mamoni RL, Souza MH, Blotta L. TLR-2, TLR-4 and dectin-1 expression in human monocytes and neutrophils stimulated by Paracoccidioides brasiliensis. Med Mycol. 2009; 47: 722-733. 
10. Calich VL, Pina A, Felonato M, Bernardino S, Costa TA, Loures, FV.Tolllike receptors and fungal infections: the role of TLR2, TLR4 and MyD88 in paracoccidioidomycosis. FEMS Immunol Med Microbiol. 2008; 53: 17.

11. Carbonell LM. Ultrastructure of dimorphic transformation in Paracoccidioidesbrasiliensis. J Bacteriol 1969;100:1076- 1082.

12. Cerio R, Griffiths CE, Cooper KD, Nickoloff BJ, Headington JT. Characterization of factor XIIla positive dermal dendritic cells in normal and inflamed skin. Br J Dermatol. 1989;12:421-431.

13. Chalermsarp N, Azuma M. Identification of three distinct subsets of migrating dendritic cells from oral mucosa within the regional lymph nodes. Immunology. 2009;127:558-66.

14. Clarke TB, Francella N, Huegel A, Weiser JN. In vivo down regulation of claudin genes is dependent on toll-like receptor 2 and 4 signaling. Cell Host Microbe. 2011; 9:404-14.

15. Collin M, McGovern MN, Haniffa M. Human dendritic cell subsets. Immunology. 2013; 140:22-30.

16. Cutler CW, Jotwani R. Dendritic cells at the oral mucosa interface. J Dent Res. 2006;85:678-89.

17. da Silva RP, Matsumoto MT, Braz JD et al. Differential gene expression analysis of Paracoccidioidesbrasiliensisduring keratinocyte infection. $J$ MedMicrobiol. 2011; 60: 269-280. 
18. de Alvarenga Lira ML, Pagliari C, de Lima Silva AA, de Andrade HF Jr, Duarte MI.DermaldendrocytesFXIIla+ are essentialantigenpresentingcells in indeterminateleprosy. $\quad$ in Dermatopathol. 2015;37:269-73.

19. de Araújo MS, Alves PM, de Lima LM, da Silva MF, de Lima Pereira SA, Rodrigues $\mathrm{V} \mathrm{Jr}$, Rodrigues DB. Evaluation of in situ expression of effector and regulatory cytokines, TLR, galectins and matrix metalloproteinases in oral manifestations of paracoccidioidomycosis. Immunobiology. 2015; 220:154-63.

20. de Brito T, Furtado JS, Castro RM, Manini M. Intraepithelial parasitism as an infecction mechanism in human paracoccidioidomycosis (South American blastomycosis). Virchows Arch Abt A Path Anat. 1973;361:12938.

21. de Castro LF, Ferreira MC, da Silva RM, Blotta MH, Longhi LN, MamoniRL. Characterization of the immune response in human paracoccidioidomycosis. J Infect.2013;67:470-85.

24. Ferreira MS. Paracoccidioidomycosis. PaediatrRespir Rev. 2009;10:1615.

25. Franco M, Montenegro MR, Calich VL, Benard G. Patologia 7ª Ed. Rio de Janeiro: Guanabara Koogan; 2006.

26. Gimenez MF, Tausk F, GimenezMM, et al. Langerhans' cells in paracoccidioidomycosis. Arch Dermatol. 1987; 123: 479-481.

27. Headington JT. The dermal dendrocyte. AdvDermatol.1986;1:159-71.

28. Heath WR, Carbone FR. The skin-resident and migratory immune system in steady state and memory: innate lymphocytes, dendritic cells 
and T cells. Nat Immunol. 2013;14:978-985.

29. Kuo IH, Yoshida T, De Benedetto A, Beck LA. The cutaneous innate immune response in patients with atopic dermatitis. $J$ Allergy ClinImmunol. 2013;131: 266-278.

30. Lacaz CS. Tratado de Micologia Médica Lacaz. 9a Ed. São Paulo: Sarvier;2002.

31. Lupi O, Tyring SK, McGinnis MR. Tropical Dermatology: Fungal Tropical Diseases. J Am AcadDermatol. 2005;53:6931-51.

32. Marques SA. Paracoccidioidomycosis. ClinDermatol. 2012; 30:610-5.

33. Mendes-Giannini MJ, Bueno JP, Shikanai-Yasuda MA, Ferreira AW, Masuda A.Detection of the 43,000-molecular-weight glycoprotein in sera of patients with paracoccidioidomycosis. J ClinMicrobiol. 1989; 27: 28422845 .

34. Mendes-Giannini MJS, Hanna SA, Monteiro da Silva JL, et al. Invasion of epithelial mammalian cells by Paracoccidioides brasiliensis leads to cytoskeletal rearrangement and apoptosis of the host cell. Microbes Infect. 2004; 6:882-891.

35. Mendes-Giannini MJ, Monteiro da Silva JL, de Fátima da Silva J, Donofrio FC, Miranda ET, Andreotti PF, Soares CP. Interactions of Paracoccidioidesbrasiliensis with host cells: recent advances. Mycopathologia. 2008;165: 237-48.

36. Mendes-GianniniMJS, Soares CP, Monteiro da Silva JL, Andreotti PF. Interaction of pathogenic fungi with host cells: Molecular and cellular approaches. FEMS Immunol Med Microbiol_.2005; 45:383-94. 
37. Menino JF, Saraiva M, Gomes-Alves AG, Lobo-Silva D et al. TLR9 activation dampens the early inflammatory response to Paracoccidioides brasiliensis, impacting host survival.PLoS Negl Trop Dis. 2013;7(7):e2317.

38. Merad M, Manz MG. Dendritic cells homeostasis. Blood. 2009;113: 3418-27.

39. Minami PS. Micologia: Métodos Laboratoriais de Diagnóstico das Micoses. 1ª Ed. São Paulo: Manole; 2003.

40. Moll H, Fuchs $\mathrm{H}$, Blank $\mathrm{C}$, et al. Langerhans cells transport Leishmania major from the infected skin to the draining lymph node for presentation to antigen-specific T cells. Eur J Immunol. 1993;1595-1601.

41. Moreto TC, Marques ME, de Oliveira ML, Moris DV, de Carvalho LR, MendesRP. Accuracy of routine diagnostic tests used in paracoccidioidomycosispatients at a university hospital. Trans $R$ SocTropMedHyg. 2011;105:473-78.

42. Muniz MAS, Marchiori $\mathrm{E}$, Magnago $\mathrm{M}$ et al.Paracoccidioidomicose pulmonar - aspectos na tomografia computadorizada de alta resolução. Radiol Bras. 2002; 35:147-54.

43. Nestle FO, Di Meglio P, Jian-Zhong Q, Nickoloff BJ. Skin immune sentinels in health and disease. Nat Rev Immunol. 2009; 9:679-691.

44. Nestle FO, Filgueira L, Nickoloff BJ, Burg G. Human dermal dendritic cells process and present soluble protein antigens. J Invest Dermatol. $1998 ; 110: 762-766$.

45. Nestle FO, Nickoloff BJ. A fresh morphological and functional look at dermal dendritic cells.J CutanPathol.1995;22:385-93. 
46. Nestle FO, Zheng XG, Thompson CB, Turka LA, Nickoloff BJ. Characterization of dermal dendritic cells obtained from normal human skin reveals phenotypic and functionally distinctive subsets. J Immunol. $1993 ; 151: 6535-45$.

47.Newman SL, Holly A. Candida albicans is phagocytosed, killed and processed for antigen presentation by human dendritic cells. Infect Immun. 2001; 69:6813-22.

48. Nickoloff BJ, Turka LA. Keratinocytes: Key immunocytes of the integument. Am J Pathol. 1993; 143: 325-331.

49. Novak N, Gros E, Bieber T, Allam JP. Human skin and oral mucosal dendritic cells as 'good guys' and 'bad guys' in allergic immune responses. ClinExpDermatol. 2010;161: 28-33.

50. Nudel I, Elnekave M, Arizon M, Clausen BE, Wilensky A, Hovav AH. Dendritic cells in distinct oral mucosal tissues engage different mechanism to prime CD8+ T cells.Jlmmunol. 2011;186:891-900.

51. Ochoa MT, Loncaric A, Krutzik SR, Becker TC, Modlin RL. "Dermal dendritic cells" comprise two distinct populations: CD1+ dendritic cells and CD209+ macrophages. J Invest Dermatol. 2008;128: 2225-2231.

52. Pagliari C, Fernandes ER, Da Silva WLF, Silva AAL, Stegun FW, Duarte MIS, Sotto MN. Revisiting Langerhans cells in paracoccidioidomycosis: expression of CD207/Langerin in human cutaneous and mucosal lesions. MicrobesInfect. 2011;13: 1012-7.

53. Pagliari C, Fernandes ER, Stegun FW, da Silva WL, Seixas Duarte MI, Sotto MN. Paracoccidioidomycosis: cells expressing IL17 and Foxp3 in cutaneous and mucosal lesions. MicrobPathog. 2011;50: 263-7. 
54. Pagliari C, Sotto MN. Correlation of factor XIIla+ dermal dendrocytes with paracoccidioidomycosis skin lesions. Med Mycol. 2002; 40:407-410.

55.Pagliari C, Sotto MN. Dendritic cells and pattern of cytokines in paracoccidioidomycosis skin lesions. Am J Dermatopathol. 2003; 25:107-112.

56. Paquet P, Paquet F, Al Saleh W, Reper P, Vanderkelen A, Piérard GE. Immunoregulatory effector cells in drug-induced toxic epidermal necrolysis.Am J Dermatopathol.2000; 22: 413-417.

57. Paracoccidioidomycosis. Proceedings of the first Pan American symposium, 25-27 October 1971, Medellin, Colombia. Ann Intern Med. 1973;79:330.

58. Parise-Fortes MR, Miot HA, Kurokawa CS, Marques MEA, Marques AS. Imunologia da paracoccidioidomicose. AnBrasDermatol. 2011; 86:51625.

59. Pereira NV, Pagliari C, Fernandes ER, Guedes F, Sotto MN, Duarte MI. Interaction of human papillomavirus DNA with factor XIIlapositive dermal dendrocytes in vulvar lesions. Acta Derm Venereol. 2008;88:391-3.

60. Probst-Cousin S, Poremba C, Rickert CH, Bocker W, Gullotta F. Factor XIIla expression in granulomatous lesions due to sarcoidosis or mycobacterial infection. Pathol Res Pract. 1997; 193: 741-45.

63. Quatresooz P, Paquet P, Hermanns-Lê T, Piérard GE. Molecular mapping of Factor XIIla-enriched dendrocytes in the skin. Int J Mol Med. 2008; 22:403-409. 
64. Ramos-e-Silva M, Saraiva LES. Paracoccidioidomycosis. DermatolClin. $2008 ; 26: 257-69$.

65. Regezi JA, Nickoloff BJ, Headginton JT. Oral submucosaldendrocytes: factor XIlla+ and CD34+ dendritic cell populations in normal tissue and fibrovascularlesions.JCutanPathol. 1992;398-406.

66. Restrepo A, Salazar ME, Cano LE, Stover EP, Feldman D, Stevens DA.Estrogens inhibit mycelium-to-yeast transformation in the fungus Paracoccidioidesbrasiliensis: implications for resistance of females to paracoccidioidomycosis. Infect Immun. 1984; 46: 346-53.

67. Romani L. Immunity to fungal infections. Nat Rev Immunol. 2011;11:27588.

68. Sandoval M, de Brito T, Sotto MN, Santos RT, Franco MF. Antigen distribution in mucocutaneous biopsies of human paracoccidioidomycosis. Int J SurgPathol. 1996; 3:181-188.

69. Schröder JM. The role of keratinocytes in defense against infection. CurrOpin Infect Dis. 2010; 23:106-10.

70. Segura E, Touzot M, Bohineust A et al. Human inflammatory dendritic cells induce Th17 cell differentiation. Immunity. 2013;38:336-48.

71. Shankar J, Restrepo A, Clemons KV, Stevens DA. Hormones and the resistance of women to paracoccidioidomycosis. Clin. Microbiol. Rev. 2011;24: 296-313.

72. Shikanai-Yasuda MA, Telles Filho FQ, Mendes RP et al. Consenso em Paracoccidioidomicose. RevSocBrasMed Trop. 2006; 39:297-310. 
73. Sidrim JJC, Rocha MFG. Micologia Médica à Luz de Autores Contemporâneos $1^{1}$ Ed. Rio de Janeiro: Guanabara Koogan; 2004.

74. Simões Quaresma JA, de Oliveira MF, Ribeiro Guimarães AC, de Brito EB, de Brito RB, Pagliari C, de Brito AC, Xavier MB, Seixas Duarte MI. CD1a and_factor XIIIa_immunohistochemistry in_leprosy: a possible role of dendritic cells in the pathogenesis of Mycobacterium leprae infection. Am J Dermatopathol. 2009; 31:527-31.

75. Sotto MN, de Brito T, Silva AMG, Vidal M, Castro LGM. Antigen distribution and antigen-presenting cells in skin biopsies of human chromoblastomycosis. J CutanPathol. 2004; 31: 14-18.

76. Sotto MN, Halpern I, Kauffman MR, Pagliari C. Factor XIIla+ dermal dendrocyte parasitism in American tegumentaryleishmaniasis skin lesions. Am J Dermatopathol. 2010;32: 15-18.

77. Streilein JW. Skin-associated lymphoid tissues (SALT): origins and functions. J. Invest. Dermatol. 1983;80:12S-16S.

78. Theodoro RC, Teixeira MDM, Felipe MSS, Paduan KDS, Ribolla PM, San Blas G, Bagagli E. GenusParacoccidioides: species recognition and biogeographic aspects. PLOS ONE. 2012;7(5): e37694.

79. Valladeau J, Saeland S. Cutaneous dendritic cells.Seminimmunol. 2005; 17: $273-83$.

80.Zaba LC, Fuentes-Duculan J, Steinman RM, Krueger JG, Lowes MA. Normal human dermis contains distinct populations of CD11C+BDCA-1+ dendritic cells and CD163+FXIIIA+ macrophages.JClinInvest. 2007;117:2517-25.

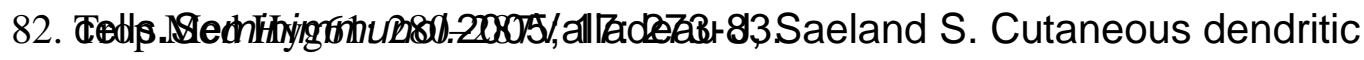


CAPÍTULO 10 - ANEXOS 


\section{Hospital das Clínicas da FMUSP \\ Comissão de Ética para Análise de Projetos de Pesquisa - CAPPesq}

\section{PROJETO DE PESQUISA}

Título: INTERAÇÃO DO PARACOCCIDIOIDES BRASILIENSIS COM CÉLULAS DENDRÍTICAS E QUERATINÓCITOS EM BIOPSIAS DE LESÕES DE PELE E MUCOSA ORAL DE DOENTES COM DIAGNÓSTICO DE PARACOCCIDIOIDOMICOSE.

Pesquisador Responsável: Mirian Nacagami Sotto

Versão: 1

Pesquisador Executante: Wellington Luiz Ferreira da Silva

CAAE: 09825612.3.0000.0068

Co-autores: Carla Pagliari

Finalidade Acadêmica Mestrado

Instituição: HCFMUSP

Departamento: DERMATOLOGIA

\section{PARECER CONSUBSTANCIADO DO CEP}

Registro on-line: 10116

Número do Parecer: 164.108

Data da Relatoria: 05/12/2012

Apresentação do Projeto: Pesquisa retrospectiva de prontuários e biopsias envolvendo o diagnostico de paracoccidioidomicose de pacientes da Clinica Dermatológica no período de 1960-1980.

Objetivo da Pesquisa: Identificação da interação do P.brasiliensis com celulas dendriticas e queratinocitos de indivíduos portadores de paracoccidioidomicose, através de técnicas de imunohistoquimica de dupla marcação e por imunofluorescencia confocal a laser, em material de biopsias.

Avaliação dos Riscos e Benefícios: Não há riscos envolvidos uma vez que a pesquisa utilizara prontuários e peças de biopsias

Comentários e Considerações sobre a Pesquisa: Não apresenta questionamentos de natureza ética

Considerações sobre os Termos de apresentação obrigatória: Sem comentários

Recomendações: Aprovação sem pendências

Conclusões ou Pendências e Lista de Inadequações: APROVADO

Situação do Parecer: Aprovado

Necessita Apreciação da CONEP: Não

São Paulo, 10 de Dezembro de 2012

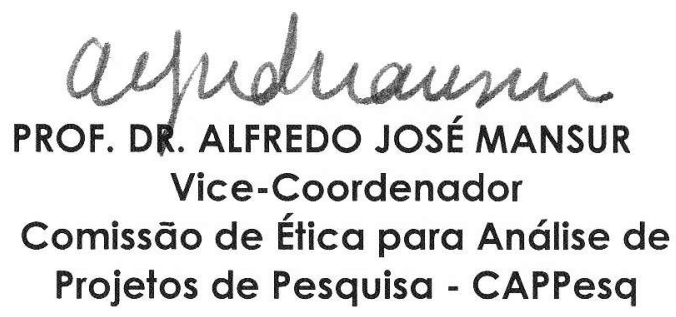

Rua Dr. Ovídio Pires de Campos, 225 - Prédio da Administração - 5 andar

CEP 05403-010 - São Paulo - SP.

5511 2661-7585 - 5511 2661-6442 ramais: 16, 17, 18 | marcia.carvalho@hc.fm.usp.br 


\title{
Paracoccidioides brasiliensis interacts with dermal dendritic cells and keratinocytes in human skin and oral mucosa lesions
}

\author{
Wellington Luiz Ferreira da Silva ${ }^{1}$, Carla Pagliari,2, Maria Irma \\ Seixas Duarte ${ }^{2}$ and Mirian N. Sotto ${ }^{1,2, *}$ \\ ${ }^{1}$ Department of Dermatology, University of São Paulo Medical School, São Paulo, Brazil and ${ }^{2}$ Department \\ of Pathology, University of São Paulo Medical School, São Paulo, Brazil \\ *To whom correspondence should be addressed. Mirian N. Sotto, Faculdade de Medicina da Universidade de São Paulo, \\ Avenida Dr. Arnaldo, 455 - sala 1118, 01246-903, São Paulo - SP, Brazil. Tel: +55-11-3061-7238; Fax: +55-11-2661-3361; \\ E-mail: mnsotto@usp.br
}

Received 24 August 2015; Revised 1 December 2015; Accepted 8 December 2015

\begin{abstract}
Paracoccidioidomycosis (PCM) is a systemic disease caused by the fungus Paracoccidioides brasiliensis and Paracoccidioides lutzii. In PCM the skin and oral mucosa are often affected. Dendritic cells and keratinocytes of the integument play a role in innate and adaptive immune response against pathogens, due to their function as antigen presenting cells. Aiming to verify the interaction of $P$. brasiliensis with these cell populations, we studied 52 skin and 47 oral mucosa samples taken from patients with proven diagnosis of PCM. The biopsies were subjected to immunohistochemical and/or immunofluorescence staining with anti-factor XIIla (marker of dermal dendrocytes), anti-CD207 (marker of mature Langerhans cells), anti-pan cytokeratins (AE1-AE3) and anti-P. brasiliensis antibodies. Analyses with confocal laser microscopy were also performed for better visualization of the interaction between keratinocytes and the fungi. In sum, $42 \%$ of oral mucosa samples displayed yeast forms in Factor XIIla dermal dendrocytes cytoplasm. Langerhans cells in skin and oral mucosa samples did not show yeast cells in their cytoplasm. In sum, $54 \%$ of skin and $60 \%$ of mucosal samples displayed yeast cells in the cytoplasm of keratinocytes. The parasitism of keratinocytes may represent a possible mechanism of evasion of the fungus to local immune mechanisms. Factor XIIla dendrocytes and keratinocytes may be acting as antigen-presenting cells to fulfill the probably impaired function of Langerhans cells in skin and oral mucosa of human PCM.
\end{abstract}

Key words: Paracoccidioidomycosis, dendritic cells, keratinocytes, immunohistochemistry, confocal laser microscopy, skin and oral mucosa.

\section{Introduction}

Paracoccidioidomycosis (PCM) is caused by dimorphic fungus Paracoccidioides brasiliensis (S1, PS2, and PS3) and
Paracoccidioides lutzii. ${ }^{1}$ PCM is a systemic disease that affects various organs, mainly the lungs. The involvement of skin and oral mucosa is very frequent. ${ }^{2}$ 
The fungus is observed in the lesions where it is recognized by the characteristic pilot wheel appearance with more than four budding yeasts adhering to the mother cell. The yeast cells parasitize macrophages and giant cells of the tissue causing an inflammatory reaction. ${ }^{3}$

Dendritic cells, as well as keratinocytes, in skin and integument are cells that play a role in innate and adaptive immunity against pathogens. ${ }^{4}$ Langerhans cells are the main antigen-presenting cells of the integuments. Other dendritic cells present in normal skin and mucosa also play a role in integument immunity against pathogens. ${ }^{5}$ Among other dendritic cells factor XIIIa dendrocytes are characterized by the cytoplasmic expression of factor XIIIa which is a pro transglutaminase involved in hemostasis. ${ }^{6}$ Normal skin displays factor XIIIa dendrocytes at the dermal-epidermal junction, around the dermal superficial blood vessels and in the adventitia of skin appendages. These cells are scarce in reticular dermis and display spindle morphology. ${ }^{7}$ Factor XIIIa dermal dendrocytes display antigen presenting function and influence lymphocyte migration in skin through tumor necrosis factor alpha production. ${ }^{8,9}$

There are few reports addressing the interaction of $P$. brasiliensis yeast cells with dendritic cells and keratinocytes at the site of human PCM lesions ${ }^{10,11}$ and in experimental conditions; ${ }^{12}$ thus, we intended to verify the interaction of $P$. brasiliensis yeast cells with these cells in skin and oral mucosa lesions.

\section{Material and methods}

\section{Oral mucosa and skin samples}

Forty-seven oral mucosa and fifty-two-skin paraffin embedded samples taken from PCM patients for diagnostic purpose were selected from the files of the Dermatopathology Laboratory of Dermatology Department of University of São Paulo Medical School. All patients were from the State of São Paulo, where Paracoccidioides brasiliensis is the agent of PCM. ${ }^{1}$

The samples were classified by the characteristics of tissue response. ${ }^{10} \mathrm{G} 1$ group comprised samples displaying well-organized granulomas (Figure 1a), G2 group exhibited poorly organized granulomas (Figure $1 b$ ) and G3 group displayed both types of granuloma.

Immunohistochemical staining for demonstration of $P$. brasiliensis yeast cells interaction with factor XIIIa dendrocytes, Langerhans cells and keratinocytes.

In sum, $4 \mu \mathrm{m}$ thick histological sections of each sample were submitted to an immunohistochemical staining technique modified from Pagliari and Sotto. ${ }^{10}$ Table 1 displays the antibodies, dilution, visualization systems, and substrate chromogens used.
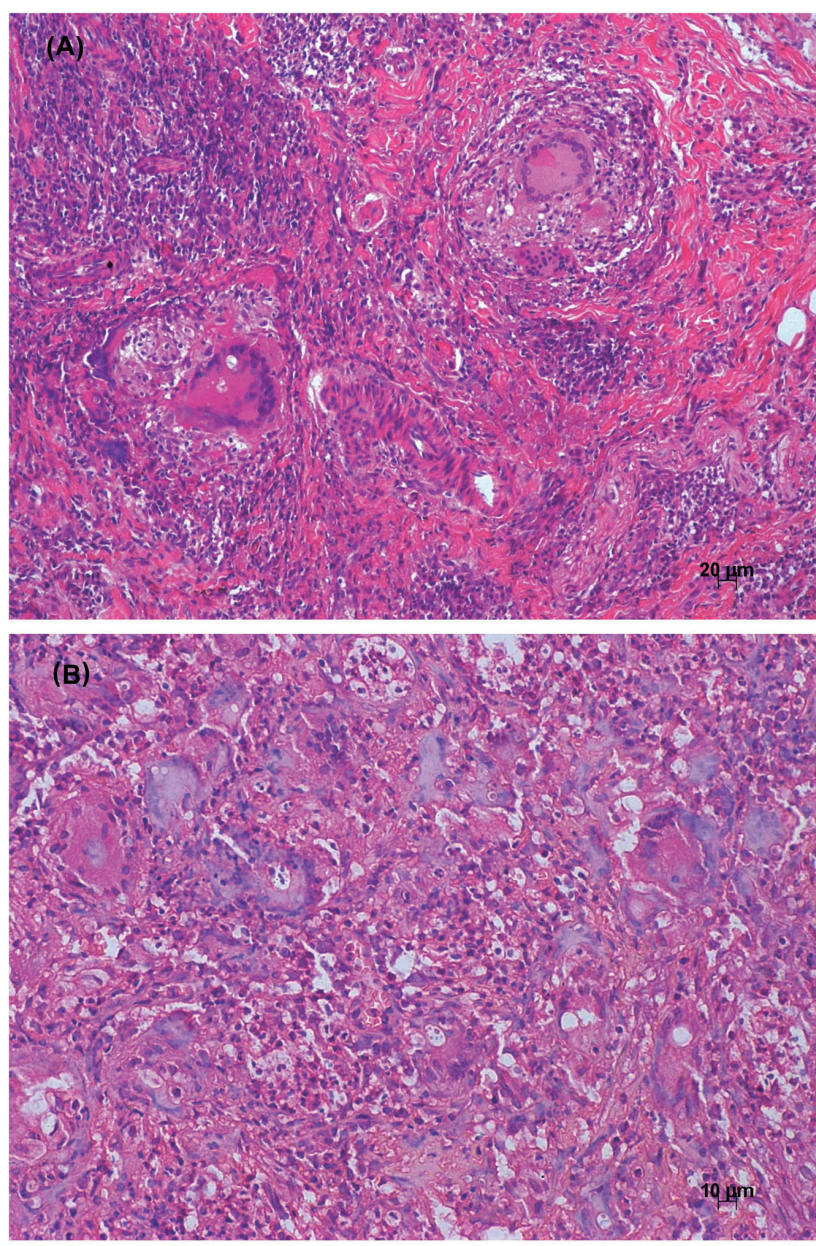

Figure 1. Paracoccidioidomycosis. Well-organized granulomatous tis sue reaction (A). Poorly organized granulomatous tissue response (B). Hematoxylin and eosin stain.

After the immunohistochemical procedures the slides were counterstained with Mayer's hematoxylin and mounted with Permount resin (SP15-100, Fisher Scientific) and glass coverslips.

Only the mucosal samples were subjected to double labeling to demonstrate Factor XIIIa dencrocytes/P. brasiliensis co-localization, because the parasitism of dermal dendrocytes in PCM skin lesions was demonstrated previously elsewhere. ${ }^{10}$

All reactions were run with positive controls. The negative controls of the reactions were obtained by the omission of the primary antibodies that were replaced by isotypic nonreagent antibodies or phosphate buffer saline solution (PBS) $\mathrm{pH}$ 7.4.

Double immunofluorescence technique to demonstrate $P$. brasiliensis within keratinocytes cytoplasm

In sum, $4 \mu \mathrm{m}$ thick dewaxed histological sections of seven skin and one oral mucosa samples were incubated for two days at $4{ }^{\circ} \mathrm{C}$, with a mixture of AE1-AE3 and anti-P. brasilensis antibodies (dilution 1/250). After washing the 
Table 1. Antibodies, visualization systems, and substrate chromogens used in the immunohistochemical double staining techniques for demonstration of Paracoccidioides brasiliensis yeast cells co-localization with dermal dendritic cells, Langerhans cells (CD207), and keratinocytes.

\begin{tabular}{|c|c|c|c|}
\hline Antibody & Dilution & Visualization system & Substrate chromogen \\
\hline $\begin{array}{l}\text { Anti- } P \text {. brasiliensis rabbit polyclonal } \\
\text { antibody }{ }^{10}\end{array}$ & $1: 300$ & $\begin{array}{l}\text { EnVision }{ }^{\mathrm{TM}} \text { G2 System/AP (K5355, } \\
\text { Dako) }\end{array}$ & $\begin{array}{l}\text { PermaGreen/AP, PermaBlue/AP } \\
\text { (K052, K051, Diagnostic ByoSystems) }\end{array}$ \\
\hline $\begin{array}{l}\text { Anti-Factor XIIIa (RB1464-P, } \\
\text { Labvision) }\end{array}$ & $1: 200$ & $\begin{array}{l}\text { Novolink }{ }^{\mathrm{TM}} \text { Polymer }(7159, \\
\text { Novocastra) }\end{array}$ & $\begin{array}{l}\text { 3,3' - Diaminobenzidine (D5637, } \\
\text { Sigma) }\end{array}$ \\
\hline CD207 (clone 12D6, Novocastra) & $1: 100$ & $\begin{array}{l}\text { Novolink }^{\mathrm{TM}} \text { Polymer }(7159, \\
\text { Novocastra) }\end{array}$ & $\begin{array}{l}\text { 3,3' -Diaminobenzidine (D5637, } \\
\text { Sigma) }\end{array}$ \\
\hline $\begin{array}{l}\text { AE1/AE3 (multi-cytokeratin) } \\
\text { (NCL-L-AE1/AE3, Novocastra) }\end{array}$ & $1 / 400$ & $\begin{array}{l}\text { LSAB Biotinylated-Link (K0690, } \\
\text { Dako) }\end{array}$ & $\begin{array}{l}\text { 3,3' - Diaminobenzidine (D5637, } \\
\text { Sigma) }\end{array}$ \\
\hline
\end{tabular}

material was submitted to incubation with the mixture of donkey anti-mouse antibody (Alexa Fluor 546, Invitrogen) and goat anti-rabbit antibody (Alexa Fluor 488, Invitrogen) diluted 1/250, during two hours in dark chamber. The slides were then washed in PBS followed by incubation with $4^{\prime}$, 6-diamidino-2-phenylindole (Sigma-Aldrich) diluted 1/100, for $30 \mathrm{~min}$ in dark chamber, and mounted with glass coverslips and mounting medium (Hydromount, National Diagnostics). Controls included staining with isotype-matched irrelevant antibodies.

Fluorescent images were acquired using UV/ Laser excitation on an LSM/Meta 510 Zeiss microscope and LSM Image Examiner software (Carl Zeiss, Standort Gottingen, Germany).

\section{Statistical analysis}

The number of samples of each group of tissue response (G1, G2. and G3) displaying P. brasiliensis co-localization with dendritic cells and keratinocytes was analyzed by Fisher's exact test. The level of significance was set at $95 \%$.

\section{Results}

The 47 oral mucosa samples comprised 13 biopsies displaying well-organized granuloma (G1) (Figure 1a), 19 samples with poorly organized granulomas (G2) (Figure 1b), and 15 samples with both types of granulomas (G3). Eleven skin samples displayed well-organized granulomas (G1), 22 poorly organized granulomas (G2), and 19 presented both kinds of granuloma formation (G3).

In sum, $42 \%$ of mucosal samples displayed $P$. brasiliensis within hypertrophic factor XIIIa dermal dendrocytes cytoplasm (Figure 2a). These cells were intermingled between the diffuse inflammatory infiltrate and involved the granulomas. Multinucleated macrophages also exhibited yeast cells within their cytoplasm (Figure 2b). Table 2 displays the statistical analyses of these results.
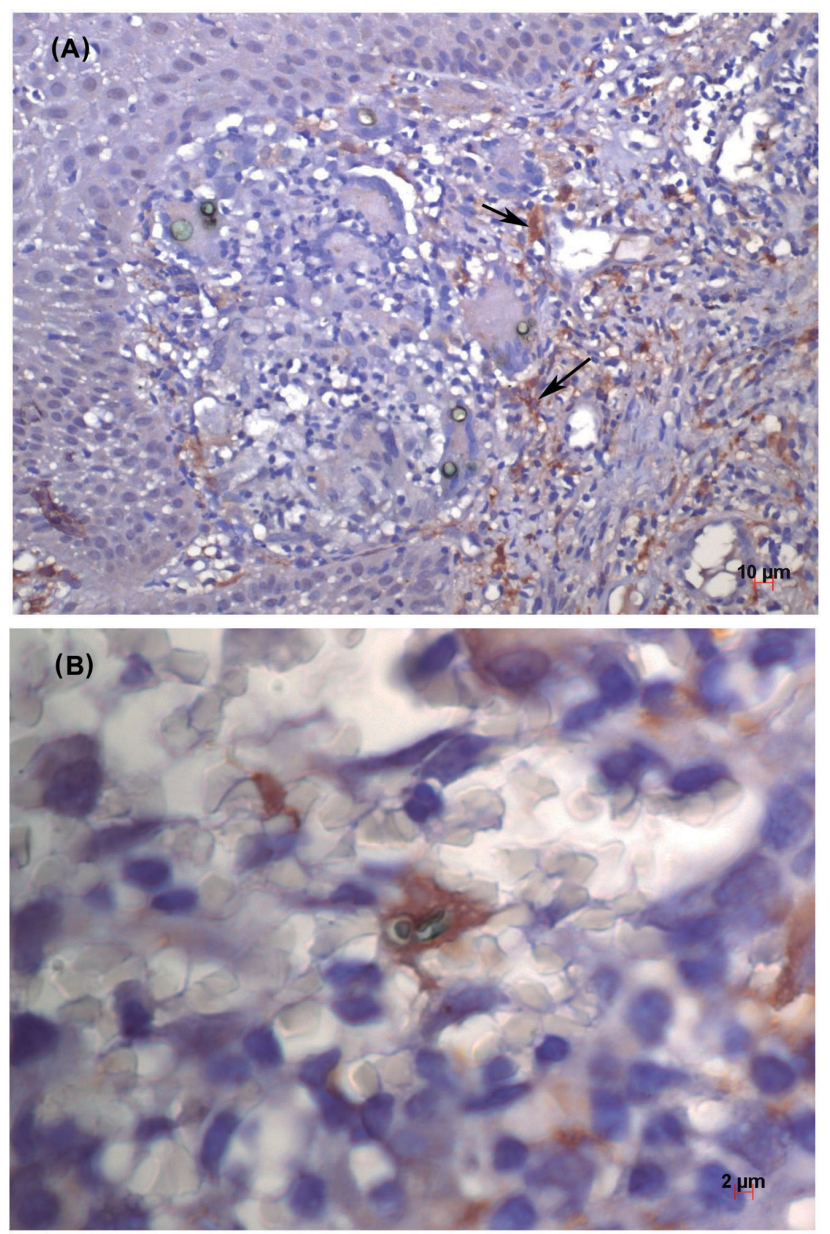

Figure 2. Paracoccidioidomycosis. Factor XIIla+ dendrocytes (arrows) around granuloma and Paracoccidioides brasiliensis yeast cells within giant cells' cytoplasm (A). Yeast cells (green) within factor XIIla+ dendrocyte cytoplasm (brown) (B). Double staining with anti-factor XIIla antibody (brown) and anti-Paracoccidioides brasiliensis antibody (green).

Fifty-two skin and forty-seven oral mucosa samples displayed scarce Langerhans cells labeled for CD207 antibody in the spinous layer of epidermis/epithelium (Figure 3a). CD207 immune stained cells were also distributed between the inflammatory infiltrate and within granuloma in skin 
Table 2. Comparison of the number of oral mucosa samples with Paracoccidioides brasiliensis yeast cells within factor XIIla+ dendrocytes' cytoplasm.

\begin{tabular}{lccc}
\hline Group of tissue response & $\begin{array}{c}\text { Number of samples with } P . \\
\text { brasiliensis yeast cells within factor } \\
\text { XIIIa+ dendrocytes cytoplasm }\end{array}$ & $\begin{array}{c}\text { Number of samples without } P . \\
\text { brasiliensis yeast cells within factor } \\
\text { XIIIa+ dendrocytes cytoplasm }\end{array}$ \\
\hline G1 & $1 / 13(8 \%)$ & $12 / 13(92 \%)$ & $.0003(\mathrm{G} 2 \mathrm{vs} \mathrm{G1)}$ \\
G2 & $14 / 19(74 \%)$ & $5 / 19(26 \%)$ & $.003(\mathrm{G} 2 \mathrm{vs}$ G3) \\
G3 & $5 / 15(33 \%)$ & $10 / 15(67 \%)$ & $.05(\mathrm{G} 3 \mathrm{vs}$ G1) \\
\hline
\end{tabular}

Note: G1 - well-organized granulomas; G2 - poorly organized granulomas; G3 - both types of granulomas. * Fisher's exact test.
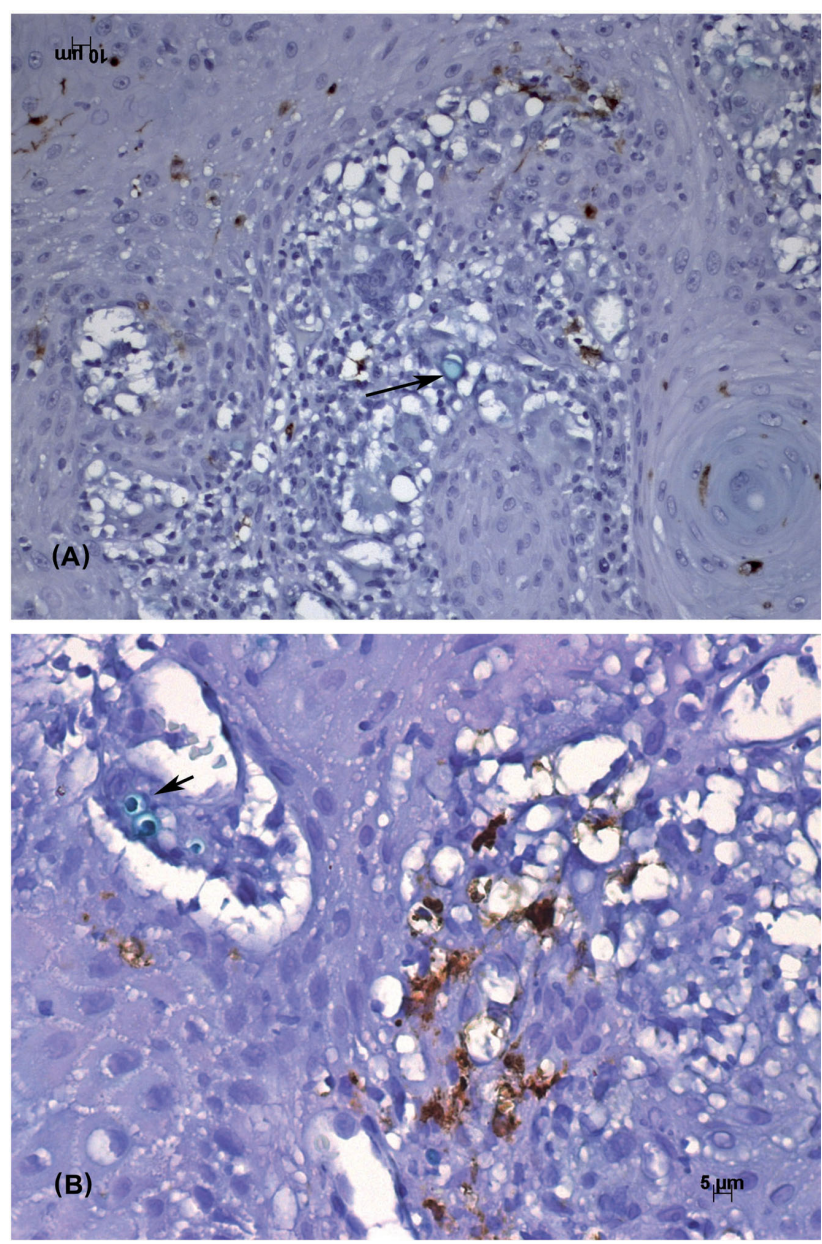

Figure 3. Paracoccidioidomycosis. Langerhans cells with short dendrites scattered among epidermal keratinocytes. Yeast cell (arrow) within macrophage cytoplasm in the dermal inflammatory infiltrate (A). Oral mucosa sample displaying Langerhans cells among the inflammatory infiltrate of the lamina propria. Yeast cells (arrow) within giant cells cytoplasm (B). Double staining with anti-CD207 antibody (brown) and anti-Paracoccidioides brasiliensis antibody (green).

(29/52 samples) and in 28/47 of oral mucosa samples (Figure $3 \mathrm{~b}$ ). No samples exhibited yeast cells within the cytoplasm of CD207 labeled cells.

Yeast cells within the cytoplasm of keratinocytes were observed in $28 / 52(54 \%)$ skin and $28 / 47(60 \%)$ oral mu-
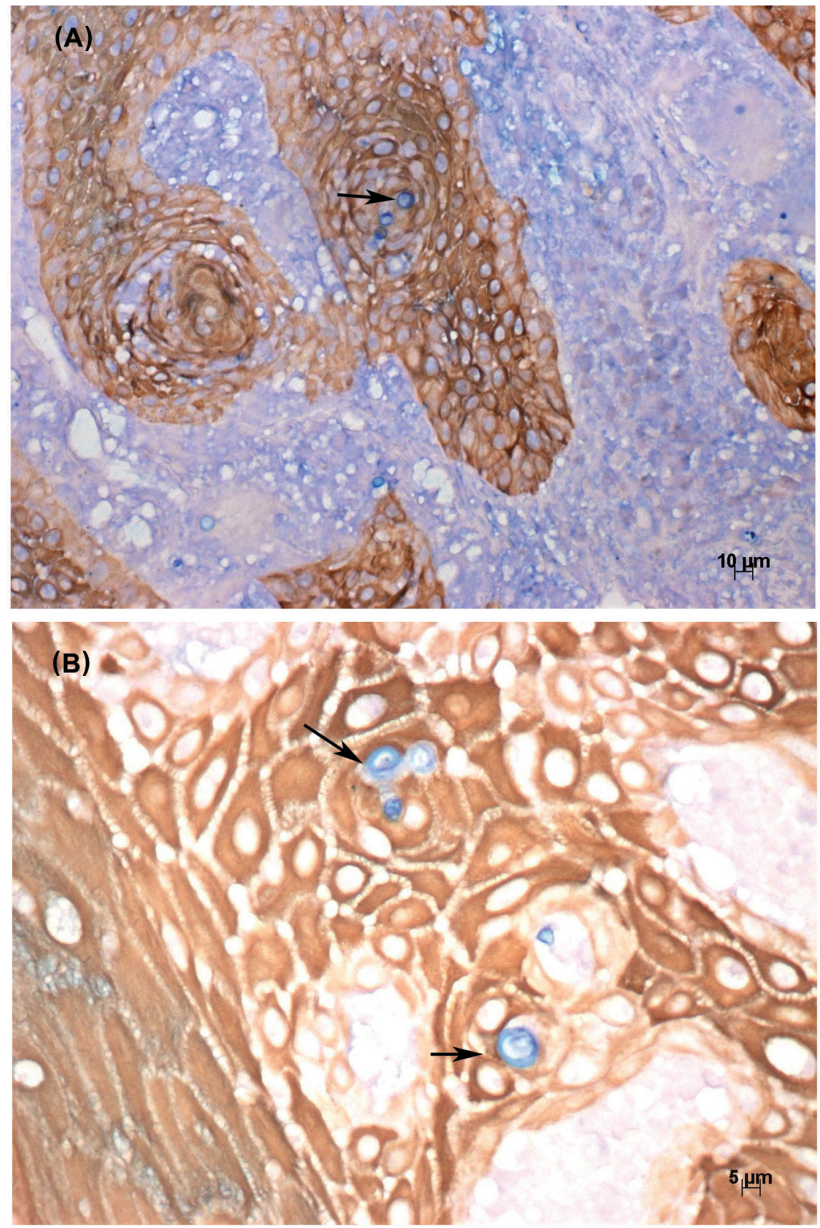

Figure 4. Paracoccidioidomycosis. Paracoccidioides brasiliensis yeast cells within keratinocytes cytoplasm (arrows) labeled for cytokeratin (A e B). Double staining with AE1-AE2 antibody (brown) and antiParacoccidioides brasiliensis antibody (blue).

cosa samples (Figure 4). Table 3 displays the comparison of the double staining positivity between samples classified according to the type of tissue response.

The confocal laser microscopy examination displayed $P$. brasiliensis yeast cells within the cytoplasm of keratinocytes and fungal antigenic deposits within the intercellular space of the squamous epithelia of the eight samples examined (Figure 5). 
Table 3. Comparison of the number of samples displaying Paracocidioides brasiliensis yeast cells within keratinocytes' cytoplasm.

\begin{tabular}{|c|c|c|}
\hline \multirow[b]{2}{*}{$\begin{array}{l}\text { Group of tissue } \\
\text { response }\end{array}$} & \multicolumn{2}{|c|}{ Oral mucosa samples $(n=47)$} \\
\hline & $\begin{array}{l}\text { Number of samples with } P \text {. } \\
\text { brasiliensis yeast cells within } \\
\text { keratinocytes cytoplasm }\end{array}$ & $\begin{array}{c}\text { Number of samples without } P \text {. } \\
\text { brasiliensis yeast cells within } \\
\text { keratinocytes cytoplasm }\end{array}$ \\
\hline G1 & $6 / 13(46 \%)$ & $7 / 13(54 \%)$ \\
\hline G2 & $12 / 19(63 \%)$ & $7 / 19(37 \%)$ \\
\hline \multirow[t]{2}{*}{ G3 } & $10 / 15(67 \%)$ & $5 / 15(33 \%)$ \\
\hline & \multicolumn{2}{|c|}{ Skin samples $(\mathrm{n}=52)$} \\
\hline $\begin{array}{l}\text { Group of tissue } \\
\text { response }\end{array}$ & $\begin{array}{l}\text { Number of samples with } P \text {. } \\
\text { brasiliensis yeast cells within } \\
\text { keratinocytes cytoplasm }\end{array}$ & $\begin{array}{c}\text { Number of samples without } P \text {. } \\
\text { brasiliensis yeast cells within } \\
\text { keratinocytes cytoplasm }\end{array}$ \\
\hline G1 & $5 / 11(45 \%)$ & $6 / 11(55 \%)$ \\
\hline G2 & $11 / 22(50 \%)$ & $11 / 22(50 \%)$ \\
\hline G3 & $12 / 19(63 \%)$ & 7/19 (37\%) \\
\hline
\end{tabular}

Note: G1 - well-organized granulomas; G2 - poorly organized granulomas; G3 - both types of granulomas. No difference when comparing the results of the groups of tissue response (Fisher's exact test).

\section{Discussion}

We demonstrated P. brasiliensis parasitism of factor XIIIa dermal dendrocytes in $42 \%$ of oral mucosa samples. These cells' parasitism was observed in $40 \%$ of skin lesions in another study. ${ }^{10}$ Factor XIIIa dermal dendrocytes are involved in the pathogenesis of other infectious diseases. These cells are abundant and hypertrophic in chromoblastomycosis skin lesions and displayed fungal antigen in their cytoplasm. ${ }^{13}$ Parasitism of Factor XIIIa dendrocytes by Leishmania amastigotes was demonstrated by our group. ${ }^{14}$ Dermal dendrocytes are cells that display phagocytic function and antigen presenting capacity. ${ }^{8}$ Considering the results obtained we speculate that this group of cells may be acting as antigen presenting cells or are only cellular targets for the fungi in human PCM. We decided to observe the frequency of co-localization of fungus yeast cells with factor XIIIa dermal dendrocytes in PCM samples showing the three types of tissue response because we formerly verified that these groups of lesions (G1, G2, and G3) displayed different cytokine profiles. ${ }^{15}$ It was interesting to observe that the number of factor XIIIa immune labeled cells displaying $P$. brasiliensis yeast cells within their cytoplasm was higher in the mucosal samples exhibiting tissue response with poorly organized granuloma (G2 group) than samples with organized granulomas (G1) and samples with tissue response with both kind of granuloma (G3 group). This result could be related to the high number of yeast cells in G2 type of tissue reaction, which is characterized by Th2 cytokines profile. ${ }^{15}$

Langerhans cells did not co-localize with $P$. brasiliensis yeast cells in both skin and oral mucosa lesions. This result is in accordance to what was observed by Sandoval et al. ${ }^{16}$ These authors demonstrated, by immune electron microscopy, that $P$. brasiliensis antigens accumulated in the macrophages but not in the Langerhans cells in human PCM mucocutaneous lesions. Langerhans cells are potent antigen presenting cells that internalize small antigen particles $(0.5-1 \mu \mathrm{m}$ in size), but the capacity of these cells to internalize great particles is reduced. ${ }^{4}$ This fact may explain why we did not observe the parasitism of Langerhans cells in PCM lesions. Otherwise, we previously demonstrated fungi antigens in S100 protein (another marker of Langerhans cells) immune labeled cells in chromoblastomycosis skin lesions. ${ }^{13}$ In the present study Langerhans cells were scarce and displayed trophic alterations in both skin and oral mucosa PCM lesions. Other studies demonstrated a decrease of Langerhans cells in the skin of human PCM lesions. ${ }^{15,17}$ The reduced number of Langerhans cells and their morphological alterations were considered the result of the action of factors produced by $P$. brasiliensis, and may reflect the depressed cellular immunity secondary to the infection. ${ }^{17} \mathrm{CD} 207$ expressing cells were previously observed reduced in number in epidermis and epithelium of oral mucosa in human PCM lesions. ${ }^{18}$

In sum, $52 \%$ of skin samples and $60 \%$ of oral mucosa samples displayed yeast cells within the cytoplasm of keratinocytes. The frequency of co-localization of fungus cells and keratinocytes did not differ in the three groups of tissue response (G1, G2, and G3) of skin and oral mucosa lesions. De Brito et al. ${ }^{11}$ demonstrated by transmission electron microscopy parasitism of keratinocytes in PCM lesions. These authors considered the parasitism of keratinocytes another 

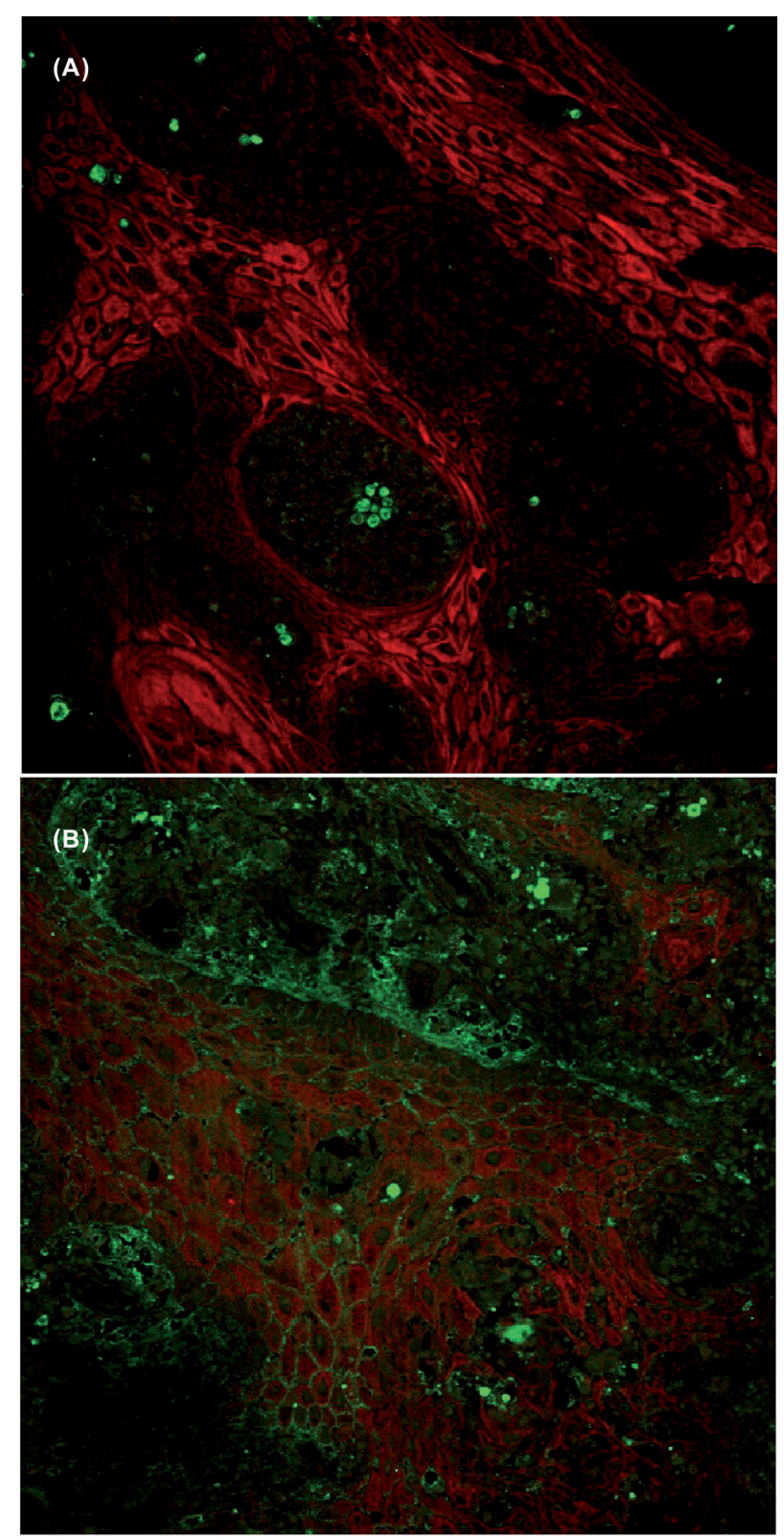

Figure 5. Paracoccidioidomycosis. Double immunofluorescence and laser confocal microscopy displaying yeast cells (green) within epidermis (red) and papillary dermis (A). Paracoccidioides brasiliensis yeast cell within keratinocyte cytoplasm and fungi antigen with intercellular fluorescence pattern (B).

mechanism of infection in human PCM. The infection of keratinocytes in PCM occurs through yeast cells, which is different than the primary infection due to conidia/mycelial fragments in the lungs. The deposit of $P$. brasiliensis antigen in the intercellular space of the epithelia was an interesting result obtained by the two immune labeling techniques performed. This same aspect was previously observed. It was considered as diffusion of the fungus antigen into the intercellular epithelial space. ${ }^{16}$ The parasitism of keratinocytes may reflect a mechanism of immunological tolerance against $P$. brasiliensis. ${ }^{12}$ Otherwise we may suggest that yeast cells within the cytoplasm of keratinocytes in skin and oral mucosa of PCM lesions is related to the activity of keratinocytes as antigen presenting cells. ${ }^{19}$ This possibility is supported since keratinocytes express many receptors for a wide variety of pathogen components. They also produce chemokines and cytokines in response to pathogenic stimuli. $^{20,21}$

In the literature there are speculations that Langerhans cells may not enhance a protective immune response against pathogens and that keratinocytes and mainly dermal dendritic cells play a role in the protective immune response. ${ }^{22}$ Based on our results, it is suggested that in human PCM integument lesions, dermal dendrocytes and keratinocytes may play a role in immunological recognition of infective agents because of the impaired function of Langerhans cells.

\section{Ethical approval}

The Ethics Committee of University of São Paulo Medical School Hospital approved the study. For this type of study formal consent is not required.

\section{Declaration of interest}

The authors report no conflicts of interest. The authors alone are responsible for the content and the writing of the paper.

\section{References}

1. Theodoro RC, Teixeira MM, Felipe MS et al. Genus Paracoccidioides: Species recognition and biogeographic aspects. PLoS One 2012; 7: e37694.

2. Franco M, Montenegro MR, Mendes RP et al. Paracoddidioidomycosis: a recently proposed classification of its clinical forms. Rev Soc Bras Med Trop 1987; 20: 129-135.

3. Moreto TC, Marques ME, de Oliveira ML et al. Accuracy of routine diagnostic tests used in paracoccidioidomycosis patients at a university hospital. Trans R Soc Trop Med Hyg 2011; 105 : 473-478.

4. Valladeau J, Saeland S. Cutaneous dendritic cells. Sem Immunol 2005; 17: 273-283.

5. Merad M, Manz MG. Dendritic cells homeostasis. Blood 2009; 113: 3418-3427.

6. Cerio R, Griffiths CE, Cooper KD et al. Characterization of factor XIIIa positive dermal dendritic cells in normal and inflamed skin. Br J Dermatol 1989; 12: 421-431.

7. Quatresooz P, Paquet P, Hermanns-Lê T et al. Molecular mapping of Factor XIIIa-enriched dendrocytes in the skin. Int J Mol Med 2008; 22: 403-409.

8. Nestle FO, Filgueira L, Nickoloff BJ et al. Human dermal dendritic cells process and present soluble protein antigens. J Invest Dermatol. 1998; 110: 762-766.

9. Paquet P, Paquet F, Al Saleh W et al. Immunoregulatory effector cells in drug-induced toxic epidermal necrolysis. Am J Dermatopathol 2000; 22: 413-417. 
10. Pagliari C, Sotto MN. Correlation of factor XIIIa+ dermal dendrocytes with paracoccidioidomycosis skin lesions. Med Mycol 2002; 40: 407-410.

11. de Brito T, Furtado JS, Castro RM et al. Intraepithelial parasitism as an infection mechanism in human paracoccidioidomycosis (South American blastomycosis). Virchows Arch Abt A Path Anat 1973; 361: 129-138.

12. da Silva RP, Matsumoto MT, Braz JD et al. Differential gene expression analysis of Paracoccidioides brasiliensis during keratinocyte infection. J Med Microbiol 2011; 60: 269-280.

13. Sotto MN, de Brito T, Silva AMG et al. Antigen distribution and antigen-presenting cells in skin biopsies of human chromoblastomycosis. J Cutan Pathol 2004; 31: 14-18.

14. Sotto MN, Halpern I, Kauffman MR et al. Factor XIIIa+ dermal dendrocyte parasitism in American tegumentary leishmaniasis skin lesions. Am J Dermatopathol 2010; 32: 15-18.

15. Pagliari C, Sotto MN. Dendritic cells and pattern of cytokines in paracoccidioidomycosis skin lesions. Am J Dermatopathol. 2003; 25: 107-112.
16. Sandoval M, de Brito T, Sotto MN et al. Antigen distribution in mucocutaneous biopsies of human paracoccidioidomycosis. Int J Surg Pathol 1996; 3: 181-188.

17. Gimenez MF, Tausk F, Gimenez MM et al. Langerhans' cells in paracoccidioidomycosis. Arch Dermatol 1987; 123: 479-481.

18. Pagliari C, Fernandes ER, da Silva WLF et al. Revisiting Langerhans cells in paracoccidioidomycosis: expression of CD207/Langerin in human cutaneous and mucosal lesions. Microbes Infect 2013; 13: 1012-1017.

19. Nickoloff BJ, Turka LA. Keratinocytes: Key immunocytes of the integument. Am J Pathol 1993; 143: 325-331.

20. Kuo IH, Yoshida T, De Benedetto A et al. The cutaneous innate immune response in patients with atopic dermatitis. J Allergy Clin Immunol 2013; 131: 266-278.

21. Heath WR, Carbone FR. The skin-resident and migratory immune system in steady state and memory: innate lymphocytes, dendritic cells and T cells. Nat Immunol 2013; 14: 978-985.

22. Asahina A, Tamaki K. Role of Langerhans cells in cutaneous protective immunity: is the reappraisal necessary? J Dermatol Sci 2006; 44: 1-9. 